Thaiany QueVedo Melo

\title{
Análise da expressão das proteínas Rab anterior à agregação proteica associada a neurodegeneração
}

\author{
Dissertação apresentada à Faculdade de \\ Medicina da Universidade de São Paulo para \\ obtenção do título de Mestra em Ciências \\ Programa de Fisiopatologia Experimental \\ Orientadora: Profa. Dra. Merari de Fátima \\ Ramires Ferrari
}

São Paulo 
Dados Internacionais de Catalogação na Publicação (CIP)

Preparada pela Biblioteca da

Faculdade de Medicina da Universidade de São Paulo

Creprodução autorizada pelo autor

\section{Melo, Thaiany Quevedo}

Análise da expressão das proteínas Rab anterior à agregação proteica

associada a neurodegeneração / Thaiany Quevedo Melo. -- São Paulo, 2012.

Dissertação(mestrado)--Faculdade de Medicina da Universidade de São Paulo Programa de Fisiopatologia Experimental.

Orientadora: Merari de Fátima Ramires Ferrari.

Descritores: 1.Doenças neurodegenerativas 2.Transporte proteico 3.Proteína Rab 4.Alfa-sinucleína 5.Proteínas tau 6.Peptídeos beta-amilóides

USP/FM/DBD-120/12 
Sua força me fez forte,

Seu tempo me fez preparada, Quando eu sabia o nada, O Senhor foi tudo,

Suas lições me fizeram saber, Que o Senhor me guiaria, Só posso sentir a gratidão. 
À minha família pelo apoio e carinho imprescindíveis durante todo tempo.

Aos professores Moacir Nunes, Pola, Francesco, Joyce ,Sérgio Alexandre, Marcelo, Fábio Morales, Manolo, Mani pelo apoio fundamental para o desenvolvimento da minha vida acadêmica e pessoal, pela amizade, pelas palavras, pela confiança, pelo sentimento sincero, porque foi verdadeiro carregarei para sempre dentro de mim.

Especialmente ao professor Julinho e seu irmão Augusto, pela amizade, pelo carinho, pela oportunidade, e acima de tudo por acreditarem em mim quando eu mesma não sabia do que era capaz. Não existem palavras que possam expressar minha gratidão por esses dois professores.

Aos meus amigos que partilharam um edificante Ensino Médio comigo, que dividiram alegrias, tristezas, angústias, risadas dentre inúmeros sentimentos que fizeram parte de uma época linda que hoje quando conversamos percebemos o quão era valiosa.

À amiga Karina Fasson pela sua amizade, apoio e incentivos durante o desenvolvimento desse estudo.

À minhas grandes amigas Damaris Alegretti e Grace Moysés pelo carinho, companhia, e principalmente pelos ótimos momentos que me proporcionaram. Nunca irei esquecer.

Aos amigos que tive sorte de ter como companhia durante toda graduação, e fizeram esse período ser inesquecível.

A Jorgivan Dias pelo apoio, pela amizade, pelo amor, por todas as risadas, por ter sido a melhor companhia que eu poderia ter.

À amiga Ana Paula Fernandes pela amizade e apoio principalmente no período de finalização desse estudo. 


\section{Agradecimentos}

À Dra. Merari de Fátima Ramires Ferrari pela orientação, pela dedicação e pelos exemplos dados propositalmente e espontaneamente durante todo desenvolvimento desse estudo, os profissionais e os pessoais.

À aluna Aline Mendes D’Unhão pela ajuda com os animais idosos.

À Tânia pelo apoio, pela atenção, pela amizade, fundamentais para a resolução dos problemas burocráticos.

Aos professores: Regina Célia Migroni Netto, Angela Morgante, Luciana Haddad do Instituto de Biociências, pela disponibilidade de espaço e equipamentos.

Aos colegas de laboratório pela colaboração.

Ao programa de Fisiopatologia Experimental pela oportunidade. 


\section{Apoio financeiro}

Este estudo foi desenvolvido com bolsa de estudos concedida pela Fundação de Amparo à Pesquisa do Estado de São Paulo (FAPESP) (processo 2009/122009) e auxílios à pesquisa da Fapesp e CNPq (2008/04480-9 e 472042/2008-4, respectivamente). 


\section{Sumário}

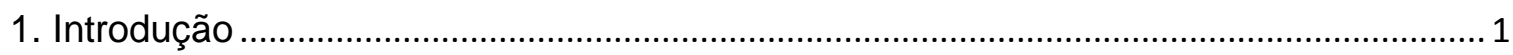

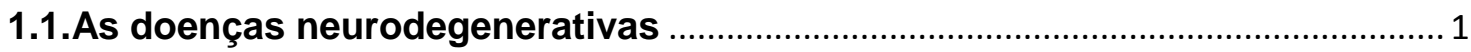

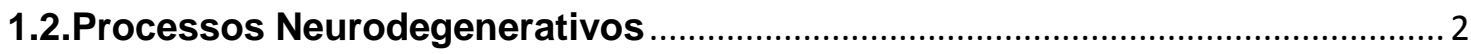

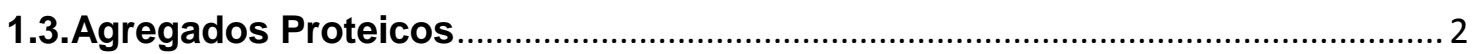

1.4.0 tráfego intracelular e as proteínas Rab ......................................................... 5

1.5.As proteínas Rab e as proteínas motoras …...................................................... 10

1.6.Proteínas motoras e o tráfego mitocondrial ........................................................ 11

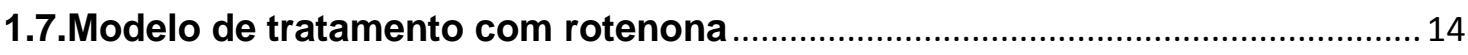

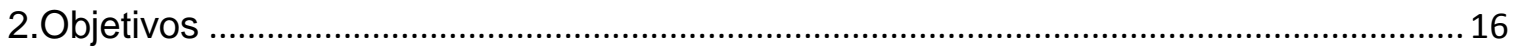

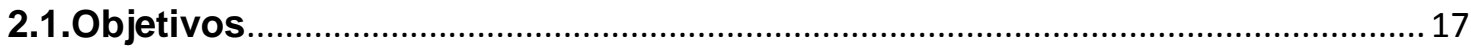

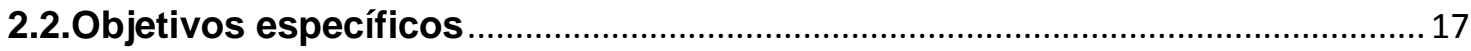

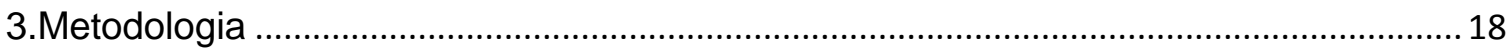

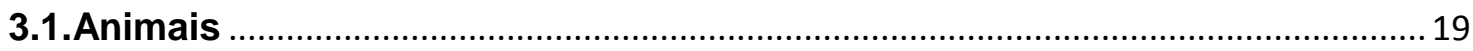

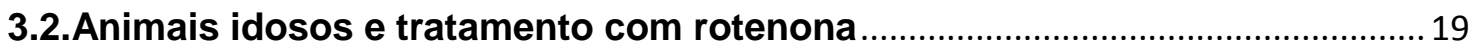

3.3.Análise geral do peso e atividade locomotora após o tratamento com

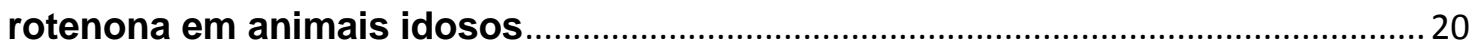

3.4.Cultura de células do mesencéfalo, hipocampo e ponte ..................................... 20

3.6. Extração de proteína e Western Blotting para análise das proteínas Rab e

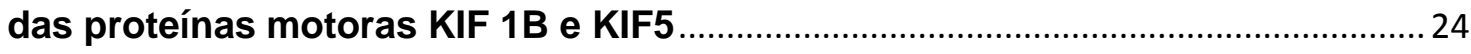

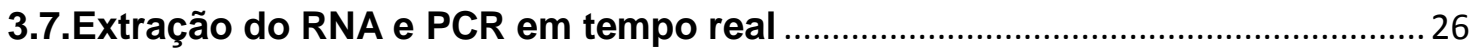

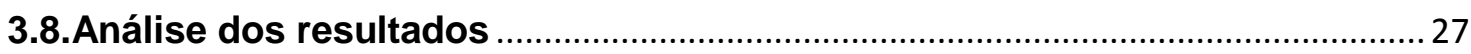

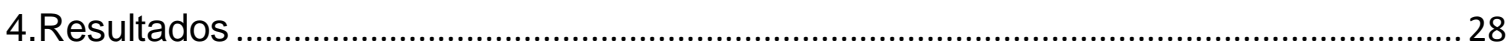

4.1.Animais, tratamento com rotenona e comportamento ...................................... 29

4.2.Análise da expressão das proteínas Rab em ratos idosos................................ 31

4.3. Análise da expressão das proteínas motoras relacionadas ao transporte

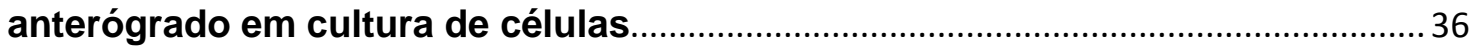

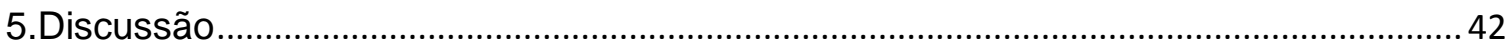

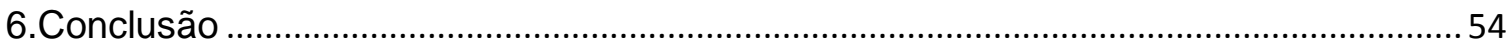

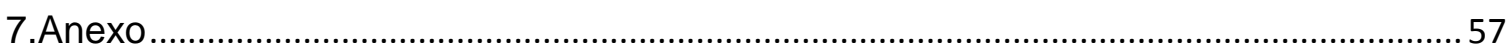

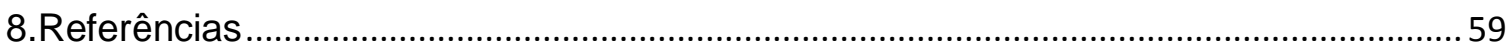




\section{Lista de Figuras}

Figura 1. Representação esquemática da participação das proteínas Rab no tráfego intracelular.

Figura 2.Modelo de transporte de mitocôndrias dependente de microtúbulos, cinesina e dineína.

Figura 3. Esquema representativo do campo-aberto 20

Figura 4. Imagens representativas de secções do encéfalo de rato neonato contendo as regiões dissecadas para a cultura de células.

Figura 5. Variação semanal do peso dos ratos e análise da atividade locomotora submetidos a exposição com DMSO ou rotenona

Figura 6. Expressão proteica e gênica das proteínas Rab 1, 4, 5, 6 e 11 no hipocampo de ratos Lewis idosos tratados com DMSO ou rotenona $1 \mathrm{mg} / \mathrm{kg} / \mathrm{dia}$ durante 1 mês.

Figura 7. Expressão proteica e gênica das Rab 1, 4, 5, 6 e 11 na substância negra de ratos Lewis idosos expostos a DMSO ou a $1 \mathrm{mg} / \mathrm{kg} / \mathrm{dia}$ de rotenona durante 1 mês. .33

Figura 8. Expressão proteica e gênica das Rab 1, 4, 5, 6 e 11 no locuscoeruleus de ratos Lewis idosos expostos a DMSO ou a $1 \mathrm{mg} / \mathrm{kg} / \mathrm{dia}$ de rotenona durante 1 mês.

Figura 9. Expressão gênica das Rab3 e 32 no hipocampo, substância negra e locus coeruleus.

Figura 9. Expressão das KIF 1 e 5 em culturas de células do hipocampo expostas a DMSO ou rotenona

Figura 10. Expressão das KIF 1 e 5 em culturas de células da Substância negra expostas a DMSO ou rotenona

Figura 11. Expressão das KIF 1 e 5 em culturas de células do locuscoeruleus expostas a DMSO ou rotenona. 


\section{Lista de Abreviaturas}

DNA

RNA

EDTA

EGTA

BSA

CEMIB

$\mathrm{KCL}$

$\mathrm{NaCl}$

$\mathrm{KH}_{2} \mathrm{PO}_{4}$

DMSO

$\mathrm{CO}_{2}$

SDS

GEF

GDP

GTP

$\mathrm{NaHCO}_{3}$

GDI

$\mathrm{Ca}^{2+}$

$\mathrm{K}^{+}$

HRP ácido desoxirribonucleico

ácido ribonucleico

ácido etilenodiamino tetra-acético

ácido etilenoglicol tetra-acético

albumina de soro bovino

Centro Multidisciplinar para Investigação Biológica

Cloreto de potássio

cloreto de sódio

dihidrogenofosfato de potássio

dimetilsulfóxido

dióxido de carbono

dodecil sulfato de sódio

fator de troca do nucleotídeo guanina

guanosina difosfato

guanosina trifosfato

hidrogenocarbonato de sódio

inibidor da dissociação do nucleotídeo guanina

íon de cálcio (cátion)

íon de potássio (cátion)

peroxidase de rábano 


\section{RESUMO}

Melo TQ. Análise da expressão das proteínas Rab anterior à agregação proteica associada À neurodegeneração. [dissertação]. São Paulo: Universidade de São Paulo, Faculdade de Medicina, 2012.

A neurodegeneração é um processo onde ocorre morte celular progressiva. $O$ tráfego neuronal anterógrado e retrógado, e entre os compartimentos é essencial para a viabilidade celular. As proteínas Rabs pertencem à família de pequenas GTPases, com funções de tráfego de vesículas e organelas, para realizarem sua função as proteínas Rab podem recrutar proteínas motoras como as KIF $1 \mathrm{~B} \alpha \mathrm{e}$ KIF 5, responsáveis pelo transporte anterógrado mitocondrial. A associação do distúrbio do tráfego intracelular com doenças neurodegenerativas tem sido tema de estudos recentes. Com isso o objetivo do presente trabalho é analisar a expressão das proteínas Rab, bem como estudar as proteínas motoras que podem contribuir para o esclarecimento sobre os distúrbios no tráfego intracelular que antecedem a formação de agregados proteicos envolvidos em neurodegeneração. Para tanto, utilizou-se o modelo de tratamento com rotenona para indução de agregados em Ratos Lewis idosos que foram expostos a rotenona durante 4 semanas, em seguida foram avaliados os níveis de expressão das proteínas Rab no hipocampo, substância negra e locus coeruleus, por western blotting. Foram analisados também os níveis de expressão das proteínas motoras KIF1Ba e KIF5 antes e durante a formação de agregados proteicos, em culturas de células, de ratos Lewis neonatos, do hipocampo, substância negra e locus coeruleus tratadas com rotenona por 24 horas ou 48 horas nas concentrações de $0,1 \mathrm{nM}, 0,3 \mathrm{nM}$ e $0,5 \mathrm{nM}$. Foi observado diminuição dos níveis de expressão das proteínas Rab 1 nas regiões do hipocampo e locus coeruleus. Houve aumento de expressão das Rab 4,5 e 6 no hipocampo, porém na substância negra a expressão da Rab 1 aumentou e da Rab 6 diminuiu. Já no locus coeruleus in vivo a Rab 6 aumentou, mas as Rab 1, 5 e 11 diminuíram sua expressão. Já a expressão da KIF 5 aumentou com o tratamento de $0,1 \mathrm{nM}$ de rotenona e diminuiu após $0,5 \mathrm{nM}$ do xenobiótico por 48 horas in vitro, na mesma região. Na substância negra aumentaram as KIFs $1 \mathrm{~B} \alpha$ e 5 após o tratamento com $0,5 \mathrm{nM}$ por 48 horas in vitro, mas diminuíram as KIF $1 \mathrm{~B} \alpha$ e 5 após o tratamento com 0,3nM por 24 horas e KIF 5 após o tratamento com $0,1 \mathrm{nM}$ por 48 horas. Esses resultados permitem concluir que a expressão de proteínas importantes para o tráfego mitocondrial e de vesículas encontramse alteradas e fazem parte dos eventos intracelulares que antecedem a neurodegeneração.

Descritores: 1.Doenças neurodegenerativas 2. Transporte proteico 3. Proteína Rab 4. Alfa-sinucleína 5. Proteínas tau 6. Peptídeos beta-amiloides 


\begin{abstract}
Melo TQ. Análise da expressão das proteínas Rab anterior à agregação proteica associada À neurodegeneração. [dissertation]. São Paulo: University of São Paulo, Medicine School, 2012.

Neurodegeneration is a process that leads to progressive cell death. The anterograde and retrograde neuronal traffic as well as the traffic between compartments are essential for cell viability. The Rab proteins belong to the small GTPases family with function of vesicles and organelle trafficking. Rab proteins can recruit motor proteins such as KIF $1 \mathrm{~B} \alpha$ and KIF 5 that are responsible for anterograde mitochondrial transport. The association of intracellular traffic disturb with neurodegenerative diseases have been theme of recent studies. Thereat the objective of this study is analyze the expression of Rab and motor proteins that can contribute for the understanding about the disturb of the intracellular traffic that precedes protein aggregation involved in neurodegeneration. For this purpose it was employed the model of rotenone treatment for induction of aggregation in aged Lewis rats that were exposed to rotenone during 4 weeks in order to evaluate Rabs expression. The levels of motor proteins KIF $1 \mathrm{~B} \alpha$ and KIF 5 expression were evaluated before and during the formation of protein aggregates in hippocampus, substantia nigra and locus coeruleus cell cultures of neonates Lewis rats, exposed to rotenone for 24 hours or 48 hours in the concentrations of $0.1 \mathrm{nM}, 0.3 \mathrm{nM}$ or $0.5 \mathrm{nM}$. It was observed decreased levels of Rab 1 expression in hippocampus and locus coeruleus. Rabs 4,5 and 6 were increased in the hippocampus, but in the substantia nigra the expression of Rab 1 increased and Rab 6 decreased. In the locus coeruleus the Rab 6 increased, but Rabs 1, 5 and 11 decreased. The expression of KIF 5 increased after $0.1 \mathrm{nM}$ of rotenone and decreased after the exposure to $0.5 \mathrm{nM}$ of for 48 hours in cultured cell from the locus coeruleus. In the substantia nigra the KIF1B $\alpha$ and KIF 5 increased after treatment with $0.5 \mathrm{nM}$ for 48 hours in vitro, but these protein decreased after treatment with $0.3 \mathrm{nM}$ for 24 hours in vitro, and KIF 5 after treatment with $0.1 \mathrm{nM}$ for 48 hours. These results allow us conclude that the expression of important proteins for the mitochondrial and vesicles traffic are altered and participate of intracellular events that precede the neurodegeneration.
\end{abstract}

Descriptors: 1. Neurodegenerative diseases 2. Protein transport 3. Rab protein 4. Alfa-sinucleína 5. Tau proteins 6 . Amyloid beta-peptides 
1.Introdução 


\section{Introdução}

\subsection{As doenças neurodegenerativas}

O potencial de envelhecimento populacional mundial aumenta com o avanço do desenvolvimento sócio-econômico-científico, por isso é importante que os estudos dos mecanismos que levam à neurodegeneração sejam encorajados para a melhora da expectativa e qualidade de vida da população(Mayeux, 2003).

De acordo com estudo populacional brasileiro, realizado com idosos numa comunidade de São Paulo, a prevalência de desordens neurodegenerativas varia de $2 \%$, entre os indivíduos com idade de 65 a 69 anos, a altíssimos $40 \%$ entre aqueles com idade superior a 84 anos(Herrera et al., 1998).

No Brasil e em outros países em desenvolvimento o estudo da epidemiologia de doenças neurodegenerativas é bastante precário. A estimativa da prevalência de neurodegeneração em países como o nosso baseia-se em estudos epidemiológicos dos países desenvolvidos. Desta forma, acredita-se que cerca de $3 \%$ da população com mais de 60 anos sejam acometidas por doenças neurodegenerativas, número que pode duplicar progressivamente a cada avanço de cinco anos na idade(Scazufca et al., 2002).

Além disso, os alvos moleculares para a prevenção e tratamento dos déficits cognitivos e demência da população idosa incluem os processos que levam à formação de agregados proteicos cuja etiologia ainda é desconhecida e urgente(Woltjer et al., 2009).

Portanto, este estudo é relevante, original e inovador, pois o assunto proposto é pouco explorado considerando sua relevância para a compreensão dos mecanismos do tráfego intracelular que levam ao acúmulo de agregados proteicos, o que é sem dúvida um passo importante para o melhor entendimento acerca dos mecanismos da neurodegeneração, sua possível terapia reversiva e até mesmo para a prevenção da morte neuronal uma vez que os primeiros sintomas relacionados ao mau funcionamento da comunicação celular sejam identificados precocemente e tratados imediatamente para a melhora das terapias anti-neurodegenerativas. 


\subsection{Processos Neurodegenerativos}

Estudos a fim de analisar os processos envolvidos no envelhecimento encefálico são realizados desde o século XIX (Abraham e Miller, 1977), mas os mecanismos responsáveis pelos acontecimentos característicos da senilidade permanecem incertos. Os conceitos relacionados sobre que o seria considerado natural durante o envelhecimento do encéfalo é bastante discutido, principalmente sobre os níveis de perda neuronal (Esiri, 2007).

A coordenação dos eventos encefálicos depende da neurotransmissão que é promovida essencialmente por fatores intracelulares responsáveis pelo transporte de organelas e moléculas sinalizadoras até seus locais de ação, assim como a organização do citoplasma, secreção eendocitose. O prejuízo do tráfego intracelular e, consequentemente, da comunicação intercelular contribui para o desencadeamento da neurodegeneração.

Muito embora a causa primária da neurodegeneração não possa ser definitivamente esclarecida por causa de seu caráter multifatorial, a importância da deficiência na neurotransmissão deve ser considerada como um dos principais mecanismos desencadeadores da morte celular, especialmente durante o envelhecimento.

Durante o envelhecimento há formação natural de placas senis contendo a proteína tauhiperfosforilada, alfa-sinucleína, neurofilamentos e peptídeo betaamiloide que se encontram distribuídas por todo o sistema nervoso central. Estas placas, que são formadas por agregados proteicos insolúveis, podem estar relacionadas à morte celular senil natural e ao desencadeamento de doenças neurodegenerativas como é o caso da doença de Alzheimer, doença de Parkinson, Esclerose Lateral Amiotrófica, doença de Huntington, demências por corpos de Lewy, doença por príons, dentre tantas outras (Trzesniewska et al., 2004).

\subsection{Agregados Proteicos}

Acúmulo de neurofilamentos e da proteína tau hiperfosforilada no citoplasma de neurônios é característico de algumas situações 
neurodegenerativas, como por exemplo, a doença de Alzheimer (Ebneth et al., 1998).

A doença de Alzheimer esporádica está intimamente relacionada com a idade e é a forma mais comum da doença. Clinicamente essa doença é caracterizada pela perda progressiva da memória e das capacidades físicas e mentais (Haass e Selkoe, 2007, Muller et al., 2010, Querfurth e LaFerla, 2010). Já patologicamente a doença é caracterizada pela perda dos neurônios do hipocampo, região responsável pela memória (Braak e Braak, 1991).

Sabe-se que a hiperfosforilação da tau é um fator importante para a inibição do transporte das mitocôndrias e de vesículas em geral (Ebneth et al., 1998), já que esta proteína estabiliza os microtúbulos do axônio permitindo o transporte motor, e também participa do processo de transporte de vesículas e organelas para o terminal sináptico (Billingsley e Kincaid, 1997).

Uma vez que os níveis de tau se elevem, as vesículas contendo APP (proteína precursora amiloide) passam a se acumular no corpo celular, já que o transporte anterógrado da APP é dependente de tau e proteínas motoras como a cinesina. O maior tempo de residência da APP no corpo celularprovoca formação de peptídeos beta-amiloides na rede trans-Golgi causando toxicidade nessa organela(Mandelkow et al., 2003) e na mitocôndria (Reddy, 2009).

$\mathrm{Na}$ doença de Alzheimer os agregados proteicos extracelulares são compostos do peptídeo beta-amiloide que pode ser encontrado junto com a proteína alfa-sinucleína em neurônios e células gliais comprometidos na atrofia sistêmica múltipla (Lantos e Papp, 1994, Yoshida, 2007), e em astrócitos e células de Schwann na esclerose lateral amiotrófica(Mezey et al., 1998).

A alfa-sinucleína é uma pequena proteína pré-sináptica de função indefinida e é a principal constituinte dos corpos de Lewy, inclusões insolúveis características de doenças neurodegenerativas como o Parkinson (Lee e Trojanowski, 2006).

A doença de Parkinson é desconhecida em cerca de $75 \%$ dos casos, sendo sua manifestação uma combinação de fatores ambientais e de suscetibilidade genética ainda não completamente entendidos (Marques et al., 2011). Esta neurodegeneração implica em deficiências motoras como tremor de repouso, lentidão e diminuição dos movimentos (bradicinesia), rigidez muscular 
e instabilidade postural, além de distúrbios do sono, comportamentais e cognitivos (Weintraub et al., 2008).

Os corpos de Lewy encontram-se distribuídos por todo o sistema nervoso central incluindo o hipotálamo, o núcleo basal de Meynert, substância negra, locus coeruleus, cerebelo, núcleo dorsal da rafe, núcleo motor dorsal do vago dentre outros(den e Bethlem, 1960, Ohama e Ikuta, 1976, Kakita et al., 1994, Wakabayashi e Takahashi, 1997), cuja importância é patente para o desenvolvimento de desordens neurodegenerativas.

A agregação proteica prejudica fisicamente o transporte intracelular já que a mobilização das vesículas e organelas fica impedida (Lee et al., 2006). No entanto a formação dos corpos de Lewy parece não ser a causa direta da morte neuronal(Wakabayashi et al., 2007). Além disso, é proposta a hipótese de que a deficiência do transporte intracelular possa ser importante para a morte neuronal podendo ser a agregação proteica secundária a estímulos apoptóticos e não sua causa primária(Gentile et al., 2008).

A conformação intermediária dos filamentos proteicos também pode ser tóxica para a célula, e não somente os agregados finais(Harrison et al., 2007). $\mathrm{Na}$ realidade, há indícios de que a agregação de proteínas mal formadas seria inclusive um mecanismo protetor intrínseco da célula (Honson e Kuret, 2008). Portanto, fica clara a importância do estudo da neurotransmissão durante as fases iniciais da agregação proteica e os fatores que a desencadeiam para 0 entendimento da neurodegeneração senil natural e outras doenças neurodegenerativas.

O papel fisiológico da alfa-sinucleina ainda não é bem definido, mas sabese que sua presença é essencial para que a neurotransmissão ocorra, além disso trabalhos sugerem que a disfunção desta proteína pode estar relacionada ao déficit da comunicação intercelular (Clayton e George, 1999, Chandra et al., 2005, Fountaine e Wade-Martins, 2007).

Jeannotte e Sidhu(2007) demonstraram que os efeitos da alfa- sinucleína sobre o desbalanço da neurotransmissão dopaminérgica e noradrenérgica, podem ser observados antes mesmo do aparecimento dos sintomas motores na doença de Parkinson, pelo desenvolvimento de desordens psíquicas, como a depressão, e problemas relacionados ao sono o que levaria ao diagnóstico precoce da neurodegeneração. 
Já foi demonstrado que a redução da alfa-sinucleína monomérica in vivo reduz sua habilidade em mediar a atividade e tráfego do transportador de noradrenalina, via associação com microtúbulos, o que poderia alterar os níveis de transportadores de noradrenalina na superfície celular e desbalanço da homeostase da transmissão noradrenérgica(Jeannotte e Sidhu, 2007).

Apesar de ser vasta a literatura em desordens neurodegenerativas, a relação entre a formação dos agregados proteicos e a progressão de desordens neurológicas, especialmente de doenças neurodegenerativas, ainda não está bem estabelecida.

Há evidências de que alterações do tráfego intracelular antecedem a formação de placas senis(Cataldo et al., 2000) refletindo em prejuízo da comunicação intercelular e efetividade sináptica o que pode ser um fator importante para a degeneração celular.

\subsection{0 tráfego intracelular e as proteínas Rab}

Alguns modelos experimentais de desordens neurodegenerativas também apresentam deficiência no sistema de transporte de organelas e vesículas antes da formação de agregados insolúveis, o que culmina com o inchaço axonal e acúmulo de proteínas motoras, organelas e vesículas no corpo do neurônio em processo degenerativo (Ganzer et al., 2003, Mandelkow et al., 2003, Stokin et al., 2005, Martin, 2007).

A célula exige um poderoso controle sobre o grande fluxo que ocorre através da membrana, necessário para que a célula possa realizar suas funções(Pereira-Leal e Seabra, 2001).

O distúrbio do tráfego intracelular pode estar intimamente relacionado às proteínas Rab, que são pequenas GTPases da superfamília das Ras, responsáveis pela formação de vesículas, motilidade entre os compartimentos celulares, ancoramento, transporte de organelas e fusão de mitocôndrias, reciclagem e autofagocitose(revisto por Stenmark, 2009) como exemplificado na figura 1. 


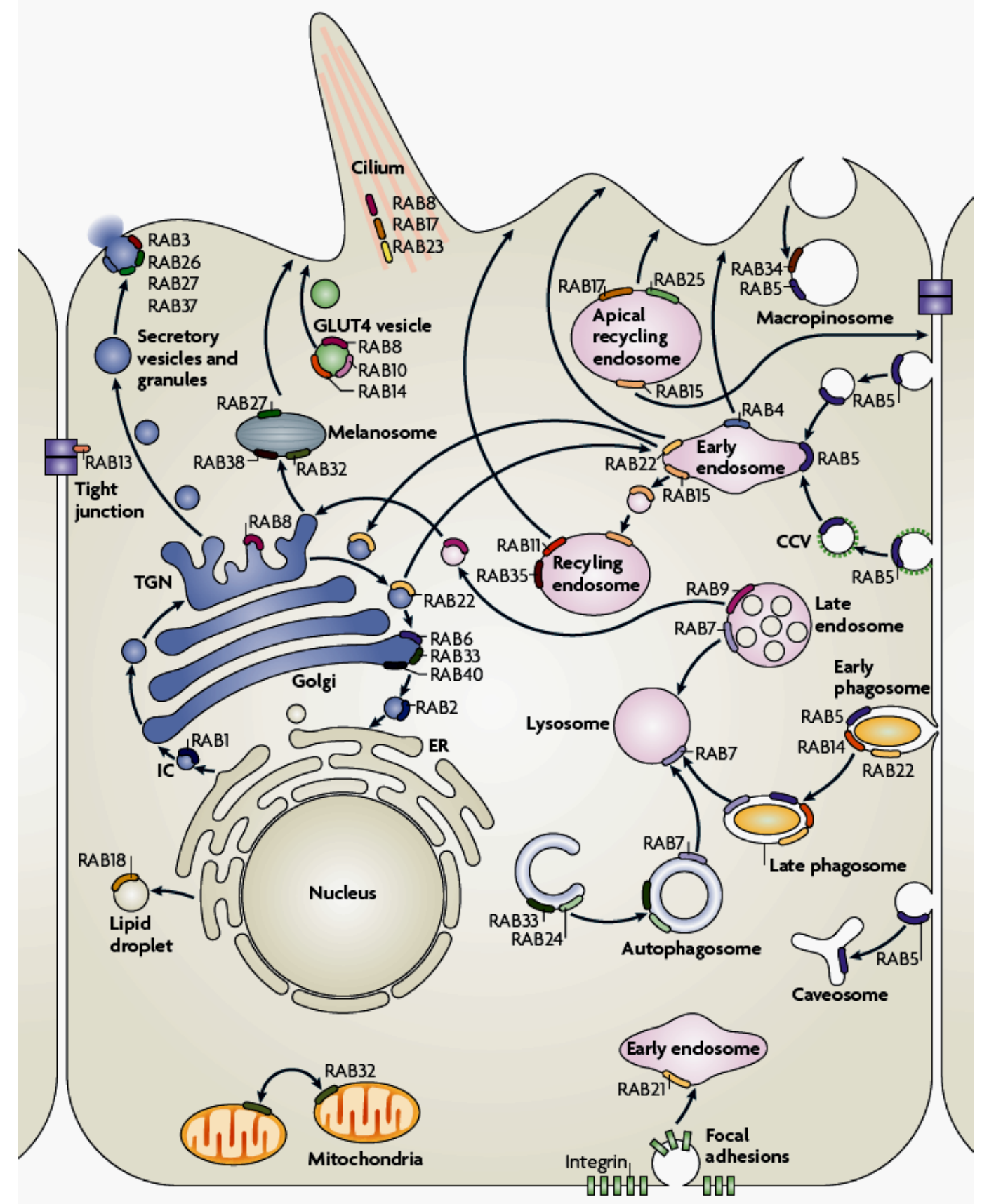

Figura 1. Representação esquemática da participação das proteínas Rab no tráfego intracelular. Extraído de Stenmark(2009). 
As vesículas e organelas são reconhecidas por proteínas Rab antes de seu ancoramento e fusão de sua membrana (Kornmann et al., 2009). As proteínas Rab em sua forma ativa recrutam proteínas efetoras que executam diversas funções incluindo reconhecimento e preparação de vesículas para fusão (Barbieri et al., 1998).

Através do ciclo GDP-GTP (inativo-ativo), as proteínas Rab funcionam como moléculas moduladoras do transporte vesicular ao longo do citoesqueleto, por meio do recrutamento de proteínas motoras específicas que asseguram a eficiente ligação e ancoramento das vesículas nos domínios alvo da membrana (Zhao et al., 2007).

O ciclo das Rab é regulado por fatores como o fator de troca do nucleotídeo guanina (GEF) promovendo a mudança do estado GDP (inativo) para o estado GTP, que é o estado ativo da proteína, as proteínas de ativação GTPases (GAPs) promovendo a mudança do estado ativo GTP para o estado GDP (Pan et al., 2006), e o inibidor da dissociação do nucleotídeo guanina (GDIs) responsáveis por bloquear a dissociação do estado GDP (DerMardirossian e Bokoch, 2005). Embora as proteínas Rab sejam proteínas homólogas, com seus sítios de ligação amino altamente conservados, seus fatores modulatórios são razoavelmente específicos para uma Rab em particular (Wang e Tang, 2006). Dentre as Rab, algumas parecem estar mais diretamente envolvidas em desordens neurodegenerativas, como as Rab 1, 4, 5, 6, 11 e 32.

Foi demonstrado que a alfa-sinucleína adicionada ao meio de cultura é internalizada pelas células via endocitose dependente de Rab5a(Sung et al., 2001).A Rab5 é uma proteína multifuncional que regula as primeiras fases da endocitose, devido a suas interações com diversos efetores, que auxiliam a ativação da forma funcional da Rab 5 , regulando assim processos de ancoramento e fusão de membranas endossomais, assim como mobilidade endossomal(Olchowik e Miaczynska, 2009).

No cérebro a proteína Rab3 possui um papel importante na liberação de neurotransmissores (Geppert et al., 1997), esta proteína encontra-se associada com as vesículas sinápticas, auxiliando no ancoramento das mesmas, e se 
dissocia dessas vesículas quando encontra-se no estado GTP (Nonet et al., 1997).

A função fisiológica da secreção de proteínas não convencionais, como aalfa-sinucleína, ainda não está esclarecida, porém, especula-se que essa proteína secretada pelas células vizinhas possa ter algum feito, além de poder ser um mecanismo celular para retirar a proteína mal formada do interior da célula (Yu et al., 2007) via exocitose dependente da Rab11a (Liu et al., 2009).

Além disso a Rab 11 localiza-se também nos endossomos de reciclagem e já foi observado que esta proteína possui um papel importante da regulação de proteínas relacionadas a reciclagem dos endossomos(Zerial e McBride, 2001).

A Rab11 ainda está envolvida ainda no tráfego de transportadores de dopamina, o que pode implicar em sua participação na neurotransmissão dopaminérgica (Furman et al., 2009).

A Rab 1 parece ter um importante papel na toxicidade dos agregados de alfa-sinucleína é atribuída, em parte, à inibição do tráfego entre o retículo endoplasmático e o complexo de Golgi por meio da Rab1 (Cooper et al., 2006), o que resulta em acúmulo de proteínas no retículo endoplasmático aumentando o estresse nessa organela, e levando também ao mau funcionamento da endocitose, característicos da doença de Parkinson (Ryu et al., 2002, Outeiro e Lindquist, 2003).

Gitler e colaboradores(2008)demonstraram que o excesso de $\alpha$-sinucleína prejudica o transporte intracelular dependente de Rab, propondo um mecanismo de toxicidade desses agregados, o qual pode ser revertido pela superexpressão da Rab1 prevenindo a perda neuronal(Fleming et al., 2008).

A regulação do tráfego e formação de vesículas endocíticas também parece ser importante para a formação das placas amiloides(Haass et al., 1992). Cataldo e colaboradores(2000), demonstraram aumento dos níveis de Rab4, relacionada com endocitose e via de reciclagem rápida (Stenmark e Olkkonen, 2001), e associação entre a Rab5 e vesículas contendo grandes quantidades de proteína beta-amiloide em pacientes com doença de Alzheimer, indicando que o desbalanço da via endocítica possa estar associado, de alguma forma, à formação de agregados proteicos.

O distúrbio do tráfego vesicular na doença de Alzheimer foi descrito há bastante tempo inclusive com a participação da proteína Rab6 no sistema de 
transporte de vesículas do complexo de Golgi para o retículo endoplasmático durante a formação de agregados contendo o peptídeo beta-amiloide (McConlogue et al., 1996). Os maiores níveis de Rab6 foram encontrados em neurônios em estágios que antecediam a formação dos depósitos de tau hiperfosforilada e a formação de placas amiloides no córtex temporal de indivíduos acometidos pela doença de Alzheimer.

A proteína Rab6 está envolvida no direcionamento das vesículas inclusive das vesículas contendo PPA do retículo endoplasmático para o Golgi, portanto o aumento da expressão de Rab6 envolve um aumento da demanda por tráfego retrógrado para o retículo endoplasmático, devido ao acúmulo de vesículas no Golgi nos casos de doenças de Alzheimer. O complexo de Golgi sofre consequências graves decorrentes de problemas no transporte intracelular o que leva à sua fragmentação podendo ser um fator determinante e irreversível para a morte neuronal em casos de Alzheimer e também esclerose lateral amiotrófica (Gonatas et al., 2006).

Anormalidades do citoesqueleto na doença de Alzheimer podem retardar a saída de proteínas do Golgi, resultando em acúmulo destas proteínas. Isto foi demonstrado em experimentos de inibição da Rab6 que extinguiu o processamento amiloidogênico da APP (McConlogue et al., 1996), sugerindo que a disfunção da Rab 6 pode retardar o processamento da APP e interferir com sua fisiologia levando à deposição de beta-amiloide.

Desta forma, o melhor entendimento do papel da Rab6 e estresse do retículo endoplasmático em resposta à doença de Alzheimer pode ajudar a identificar alvos específicos para a intervenção terapêutica nos estágios iniciais da doença (Scheper et al., 2007).

Outra proteína importante para a manutenção celular é a Rab32 que participa da fusão e fissão mitocondrial (Alto et al., 2002). A presença dessa organela em locais específicos é fundamental para a modulação, dinâmica e plasticidade sináptica (Bertoni-Freddari et al., 2007b) e sua disfunção pode levar ao desencadeamento da neurodegeneração(revisto por Soane et al., 2007), por meio inclusive da alteração no tráfego, fusão e fissão das mitocôndrias (Van Laar e Berman, 2009).

Como já mencionado, são conhecidas numerosas classes de proteínas Rab que participam do transporte vesicular e de organelas, fusão de vesículas 
nos diversos compartimentos intracelulares e no terminal sináptico e endocitose. Este transporte se dá através de ligações com proteínas do citoesqueleto, cinesinas, dineínas, outras proteínas motoras, e proteínas da organela a ser transportada (Hammer e Wu, 2002). No entanto, a importância destas proteínas para a formação dos agregados, e a ordem cronológica dos eventos intracelulares que podem contribuir para a desordem neurológica, não estão devidamente caracterizados.

\subsection{As proteínas Rab e as proteínas motoras}

Nas células eucarióticas existem redes de proteínas que formam o citoesqueleto, do qual primariamente compreende três classes distintas de filamentos: os microfilamentos, os microtúbulos e os filamentos intermediários. O papel do citoesqueleto é multifacetado, mas algumas funções estão bem estabelecidas na literatura, como a de fornecer rigidez e força para manter a forma da célula e fornecer a trajetória que permite o movimento das organelas e vesículas durante o processo de tráfego intracelular (Horgan e McCaffrey, 2011).

Duas superfamílias de proteínas são conhecidas por utilizarem os microtúbulos para realizarem seu transporte intracelular: as cinesinas e as dineínas, ambas são ATPases (Hirokawa et al., 2009).

Durante a década de 90 começaram as publicações iniciais que documentaram o envolvimento das Rabs na regulação das proteínas motoras de microtúbulo, e desde então numerosos estudos emergiram (Horgan e McCaffrey, 2011).

O prejuízo do transporte intracelular também foi demonstrado na doença de Huntington onde a proteína huntintina mutante, responsável por formação de agregados nesta doença, primeiramente prejudica o transporte de mitocôndrias antes da ocorrência de agregados e morte neuronal (Orr et al., 2008).

Muito embora um evento causativo para a deficiência da sinapse no envelhecimento não possa ser definitivamente caracterizado devido aos múltiplos determinantes da fisiologia do envelhecimento encefálico, alguns experimentos demonstraram a importância da presença de mitocôndrias no terminal sináptico para a modulação/dinâmica da sinapse e neuroplasticidade 
sináptica (Bertoni-Freddari et al., 1993, Bertoni-Freddari et al., 2004, BertoniFreddari et al., 2007b, a).

\subsection{Proteínas motoras e o tráfego mitocondrial}

Já foi demonstrado que alterações no transporte de mitocôndrias aparecem bem antes dos sintomas clássicos de neurodegeneração e podem anteceder a morte neuronal, inclusive podendo levar a doenças neurodegenerativas como o Parkinson e o Alzheimer (Martin, 2007).

As mitocôndrias são organelas vitais para as células eucarióticas. Essa organela produz energia química através do processo de fosforilação oxidativa, sendo que alguns componentes necessários para que este processo aconteça são codificados pela própria mitocôndria, mas a maioria são codificados pelo núcleo da célula. Portanto a biogênese da mitocôndria assim como seu bom funcionamento requerem comunicação e coordenação entre os genomas mitocondrial e nuclear (Wallace, 2005).

Sabe-se que para que a mitocôndria consiga realizar suas funções é imprescindível a preservação de suas membranas além da suas cadeias transportadoras de elétrons, e que quando algum desses fatores encontram-se perturbados as células sofrem apoptose (Wallace, 2005).

Doenças associadas com a disfunção mitocondrial são agrupadas em duas categorias: uma que relaciona as desordens como resultado de mutações no DNA mitocondrial, que podem afetar diretamente sua função de fosforilação oxidativa; e outra que relaciona a disfunção mitocondrial como resultado de fatores extra mitocondriais que perturbam a fisiologia da organela (Lu, 2009).

Algumas outras evidências relacionam a disfunção da mitocôndria, inclusive de seu tráfego, à neurodegeneração(revisto por Soane et al., 2007). Essa organela desempenha função fundamental na homeostase celular, metabolismo energético e disponibilidade de $\mathrm{Ca}^{2+}$ e $\mathrm{K}^{+}$intracelular. Com isso, postula-se que a disfunção mitocondrial pode contribuir para a citotoxicidade, estresse oxidativo e neurodegeneração.

As mitocôndrias são produzidas no corpo celular e transportadas para a periferia retornando para o corpo celular onde é degradada ou entra para o ciclo de biogênese. Para tanto, a membrana da mitocôndria possui sítios de ligação 
que possibilitam seu transporte rápido, lento, anterógrado, retrógrado e ancoragem(Hollenbeck e Saxton, 2005).

Especificamente dois tipos de cinesinas, as KIF 1Ba e a KIF 5 estão associadas ao transporte anterógrado de mitocôndrias em neurônios de camundongos (Nangaku et al., 1994). Outra proteína especifica de tráfego mitocondrial é a Milton que forma um complexo associado à mitocôndria, através da proteína Miro, e ao citoesqueleto para o movimento dessas organelas em direção ao terminal pré-sináptico (Stowers et al., 2002) (Figura 2). Milton é característica de drosófilas; entretanto, em mamíferos, são encontradas as suas homólogas conhecidas por GRIF-1 e OIP-106. Foi demonstrado que a diminuição da expressão dessas proteínas promove retardo do transporte anterógrado e anormalidade de distribuição das mitocôndrias em neurônios(Stowers et al., 2002, Cai et al., 2005), promovendo possível depleção de energia na sinapse. 


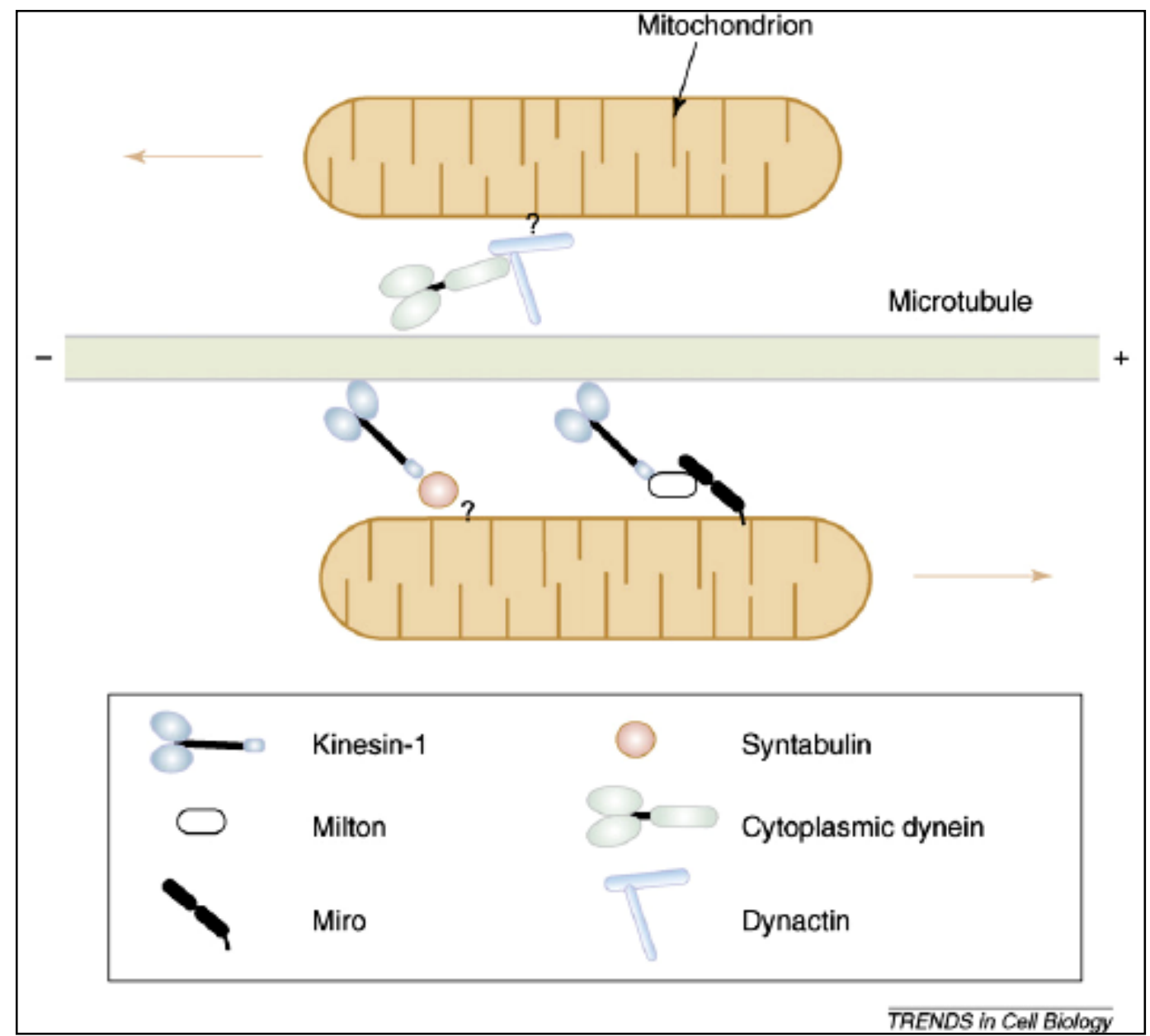

Figura 2. Modelo de transporte de mitocôndrias dependente de microtúbulos, cinesina e dineína. Participação das proteínas motoras e acessórias no transporte anterógrado (cinesina 1, milton - GRIF-1 e OIP-106, em mamíferos-, miro-1 e sintabulina) e retrógrado (dinactina e dineína citoplasmática) da mitocôndria. Figura extraída de Boldogh e Pon(2007). 
A relação entre a formação dos agregados proteicos e a progressão da morte neuronal, inclusive levando ao comprometimento de funções neurológicas, como ocorre em doenças neurodegenerativas, ainda não está bem estabelecida nos trabalhos que tratam os mecanismos de morte neuronal.

Considerando a hipótese de a formação dos agregados serem secundárias à disfunção celular, o estudo do tráfego intracelular,por meio da expressão das proteínas Rab e de tráfego das mitocôndrias, antes da formação de agregados é interessante para a elucidação dos mecanismos que levam à formação dos agregados proteicos característicos do envelhecimento do cérebro e que podem levar a doenças neurodegenerativas.

\subsection{Modelo de tratamento com rotenona}

A rotenona é um pesticida que foi primeiro utilizada em 1985 para desenvolvimento de modelos de Parkinson, pois a primeira ação observada da rotetona foi sua capacidade de promover morte dos neurônios dopaminérgicos através da inibição do complexo I da cadeia mitocondrial (Heikkila et al., 1985).Mais tarde alguns estudos demonstraram que a administração crônica de altas doses de rotenona (10-18mg/kg/dia) conduzia a lesões não específicas na região da substância negra, podendo atingir inclusive áreas periféricas do sistema nervoso(Ferrante et al., 1997).

O modelo de tratamento com rotenona para a indução de agregados a ser utilizado no presente projeto é adequado, pois exposição crônica à droga induz formação de agregados proteicos contendo alfa-sinucleína, tau e beta-amiloide em células do hipocampo, substância negra, estriado e locuscoeruleus(Chaves etal., 2010). Apesar de ter sido primeiramente caracterizada pelo envolvimento na doença de Parkinson de agricultores que utilizavam pesticidas à base de rotenona, esse fármaco é hoje melhor caracterizado e exerce seus efeitos também em células do hipocampo(Ullich e Humpel, 2009).

Desta forma, o presente estudo pretende contribuir para o avanço do conhecimento sobre a regulação destas proteínas em um modelo de agregação proteica in vitroe in vivo, para estudar as células de regiões afetadas pela neurodegeneração, associada à biologia molecular, que nos permitirá analisar a 
possível ação da rotenona sobre a síntese ou degradação de proteínas, por Western Blotting, e a expressão do RNAm, por PCR em tempo real, a fim de estabelecer a correlação dos eventos de transporte intracelular com a formação de agregados no sistema nervoso central. 
2.Objetivos 


\subsection{Objetivos}

Estudar a expressão das proteínas Rab 1,3, 4, 5, 6, 11 e 32 e das proteínas motoras envolvidas no transporte anterógrado das mitocôndrias, como as KIF 1Bae 5, e seus RNAs mensageiros, antes da formação de agregados provocados pela exposição à rotenona.

\subsection{Objetivos específicos}

1) Analisar a possível toxicidade sistêmica da rotenona, pela aferição do peso dos animais e verificação da locomoção.

2) Analisar a expressão das proteínas Rab 1, 4, 5, 6, 11 e 32, por meio de WesternBlot, no hipocampo, substância negra e locuscoeruleus de ratos com 10 meses de idade submetidos à exposição crônica à rotenona $(1 \mathrm{mg} / \mathrm{kg} / \mathrm{dia})$ infundida subcutaneamente por meio de mini bombas osmóticas durante 4 semanas.

3) Analisar a expressão dos RNA mensageiros das proteínas Rab 1, 3, 4, 5, 6, 11 e 32, por meio de PCR em tempo real, no hipocampo, substância negra e locuscoeruleusde ratos com 10 meses de idade submetidos à exposição crônica à rotenona $(1 \mathrm{mg} / \mathrm{kg} / \mathrm{dia})$ infundida subcutaneamente por meio de mini bombas osmóticas durante 4 semanas.

4) Analisar a expressão proteica, por meio de Western Blot das KIF $1 \mathrm{~B} \alpha$ e 5 em cultura de células do hipocampo, substância negra e locuscoeruleus expostas à rotenona a $0,1 \mathrm{nM}, 0,3 \mathrm{nM}$ e $0,5 \mathrm{nM}$ por 48 horas (dose-dependente), ou a 0,3nM por 24 ou 48 horas (tempo-dependente).

5) Analisar a expressão do RNAm, por meio de PCR em tempo real, das KIF $1 \mathrm{~B} \alpha$ e 5 no hipocampo, substância negra e locuscoeruleus de ratos com 10 meses de idade submetidos à exposição crônica à rotenona $(1 \mathrm{mg} / \mathrm{kg} / \mathrm{dia})$ infundida subcutaneamente por meio de mini bombas osmóticas durante 4 semanas. 
3.Metodologia 


\subsection{Animais}

Os experimentos propostos estão em conformidade com a lei federal 11794/08 (Arouca) para uso científico de animais e em conformidade com as recomendações do CONCEA, além de possuírem aprovação da comissão de ética da Faculdade de Medicina da Universidade de São Paulo CAPPesq (protocolo no. 0659/08).

Foram utilizados ratos (Rattusnorvegicus) da linhagem Lewis, adquiridos do Centro Multidisciplinar para Investigação Biológica (CEMIB) da Universidade de Campinas e criados no biotério central da Faculdade de Medicina da Universidade de São Paulo, com água e ração apropriada ad libitum. Esta linhagem foi escolhida por se tratar da única que desenvolve agregados de proteínas constitutivas após tratamento com rotenona.

\subsection{Animais idosos e tratamento com rotenona}

Todos os procedimentos feitos com os animais idosos, e experimentos foram realizados com a participação da aluna de iniciação científica Aline Mendes D'Unhão.

Foram utilizados ratos machos da linhagem Lewis, com 10 meses de idade, submetidos ao tratamento, durante 4 semanas, com $1 \mathrm{mg} / \mathrm{kg} / \mathrm{dia}$ de rotenona (Sigma) dissolvida em volumes iguais de dimetilsulfóxido (DMSO; Sigma) e polietilenoglicol (PEG; Sigma). Ketamina $(1,25 \mu \mathrm{l} / \mathrm{g})$ e xilazina $(0,5 \mu \mathrm{l} / \mathrm{g})$ dissolvidas em salina $(\mathrm{NaCl}$ 0,9\%) foram injetados peritonealmente para anestesia. A rotenona foi administrada subcutaneamente por meio de mini bombas osmóticas (Alzet), implantadas no dorso dos animais. Os animais controle receberam somente DMSO (solvente da rotenona) e PEG (1:1). Ao final de um mês de tratamento, os ratos foram eutanasiados e tiveram os encéfalos retirados, para análise da quantificação das proteínas Rab antes da agregação proteica. A quantificação das proteínas Rab foi feita através da técnica de Western Blot na substância negra, locus coeruleus e hipocampo em 10 animais, onde 5 foram expostos a rotenona e 5 eram controles. 


\subsection{Análise geral do peso e atividade locomotora após o tratamento com rotenona em animais idosos}

Os ratos idosos foram submetidos ao teste comportamental de campo aberto e pesagem semanal, antes da cirurgia e nas 4 semanas seguintesno intuito de identificar possíveis alterações na atividade locomotora e peso dos animais para garantir o bem estar animal.

A atividade locomotora espontânea foi observada em um campo aberto medindo $60 \mathrm{~cm}$ de diâmetro com barreira lateral de $50 \mathrm{~cm}$ de altura (figura3). Todo o interior da estrutura é de coloração preta. Cada animal foi colocado no meio do campo aberto e o número de quadrantes visitados por minuto foi contado (padronizou-se a permanência das duas patas traseiras por área equivalente a um quadrante).A metodologia utilizada foi uma adaptação da descrita por Diaz-Corrales e colaboradores (2005).

As medidas foram feitas no dia anterior à implantação das mini bombas, assim como nas $1^{\mathrm{a}}, 2^{\mathrm{a}}, 3^{\mathrm{a}}$ e $4^{\mathrm{a}}$ semanas após a cirurgia.
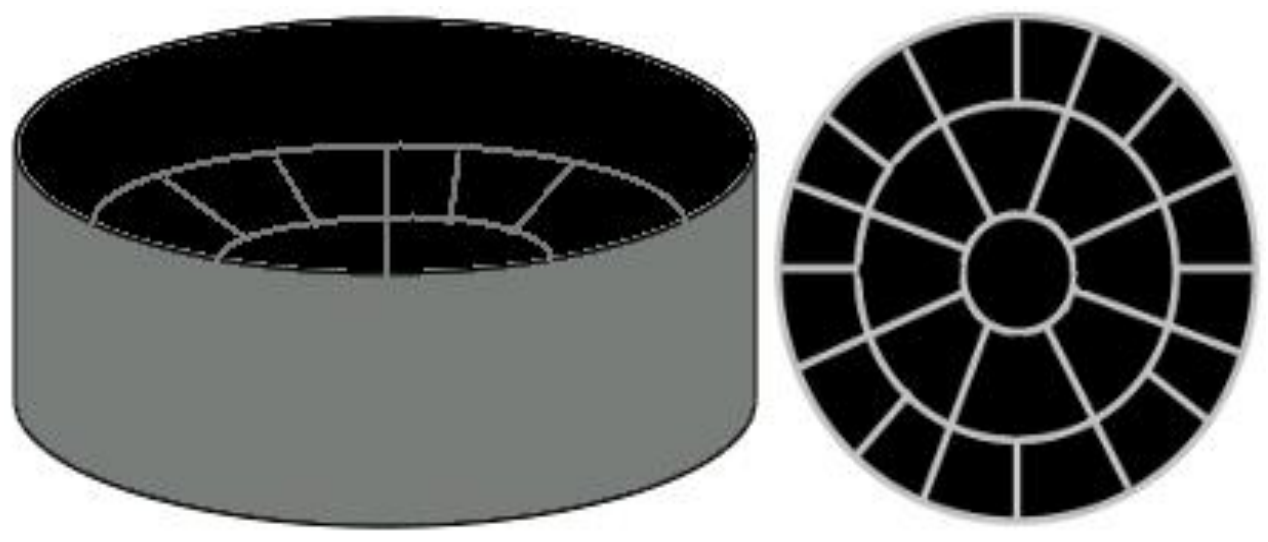

FIGURA 3.Esquema representativo do campo-aberto (esquerda) e sua vista de cima (direita).

\subsection{Cultura de células do mesencéfalo, hipocampo e ponte}

Para a cultura de células, a metodologia empregada consistiu em uma modificação do protocolo descrito por Kivell e colaboradores(2001).

Resumidamente, os encéfalos ( $n=20$, por experimento) de ratos neonatos de no máximo 1 dia de vida, foram removidos para a retirada da porção ventral do mesencéfalo (contendo a substância negra), da porção dorsal da ponte 
(contendo o locuscoeruleus) e o hipocampo, colocados em placa de petri estéril com solução fisiológica gelada. Essa solução foi preparada no momento da realização do experimento contendo $\mathrm{NaCl}, \mathrm{KCl}, \mathrm{KH}_{2} \mathrm{PO}_{4}, \mathrm{MgSO}_{4} 7 \mathrm{H}_{2} \mathrm{O}, \mathrm{NaHCO}_{3}$, glicose e água Milli $\mathrm{Q}, \mathrm{pH}$ 7,2 ajustado com $\mathrm{HCl}$, sendo então esterilizada com auxílio de um filtro de seringa com porosidade de $0,22 \mu \mathrm{m}$ em fluxo laminar.

Utilizando um estilete estéril o tronco encefálico foi separado do cérebro, e então a porção dorsomedial de uma fatia de aproximadamente $2 \mathrm{~mm}$ da ponte contendo o locuscoeruleus foi removida. Em seguida os hemisférios cerebrais foram separados e a face interna dos hemisférios foi exposta possibilitando a extração bilateral do hipocampo. A porção ventrolateral de uma fatia de aproximadamente $2 \mathrm{~mm}$ do mesencéfalo contendo a substância negra também foi isolada. A figura 4 ilustra as regiões dissecadas para a cultura de células.

A maioria das células sanguíneas e epiteliais das regiões de interesse foram removidas e o tecido permaneceu em solução fisiológica gelada até o final da retirada dos encéfalos de todos os animais.

Em seguida, as células mesencefálicas, hipocampais e pontinas foram dissociadas mecânica e quimicamente utilizando para isso uma tesoura estéril e tripsina $0,05 \%$ (Gibco), respectivamente, a incubação da tripsina ocorreu à $37^{\circ} \mathrm{C}$ durante 40 minutos em banho maria mantido sob agitação. Após a incubação com tripsina foi adicionado inibidor de tripsina $0,006 \%$ (Gibco) à solução contendo as células sendo em seguida novamente dissociadas utilizando uma pipeta Pasteur.

Após a dissociação, a solução contendo as células foi centrifugada a $300 \mathrm{~g}$ por 5 minutos, para que as células se precipitassem. Em seguida as células foram suspensas em meio de cultura Neurobasal A (Invitrogen) suplementado com l-glutamina (250M, Sigma), glutamax (250M, Gibco), complexo B27 (2\%, Invitrogen), gentamicina (40mg/l, Invitrogen), e então contadas utilizando uma câmara de Neubauer e solução de azul de tripan a 5\% (Gibco). Em seguida, foi calculada a quantidade de células por poço, de maneira que foram plaqueadas, separadamente, na concentração de 1800 células/mm2 em placas de cultura (Nunc) tratadas no dia anterior com poli-d-lisina 10 $\mathrm{gg} / \mathrm{ml}$ (Sigma),ou em placas de petri de $35 \mathrm{~mm}$ de diâmetro (Nunc). Esta cultura foi previamente caracterizada e apresenta $50 \%$ de neurônios e $50 \%$ de células gliais (majoritariamente astrócitos). 
O tratamento das placas de cultura com poli-d-lisina foi feito durante 1 hora em fluxo laminar, sendo então vedadas e armazenadas à $4^{\circ} \mathrm{C}$, e utilizadas no dia seguinte após 3 lavagens com água Milli $Q$ e incubação com soro fetal bovino 10\% (Gibco) durante aproximadamente 2 horas em ambiente estéril, com o objetivo de proporcionar melhor aderência dos neurônios às placas e fornecer uma série de fatores humorais e proteínas que favorecem a estabilização das células.

As células plaqueadas foram cultivadas em estufa contendo $5 \%$ de $\mathrm{CO} 2$ à temperatura de $37^{\circ} \mathrm{C}$ durante nove dias tendo o meio de cultura trocado três horas depois do plaqueamento das células e a cada três dias de cultivo. 

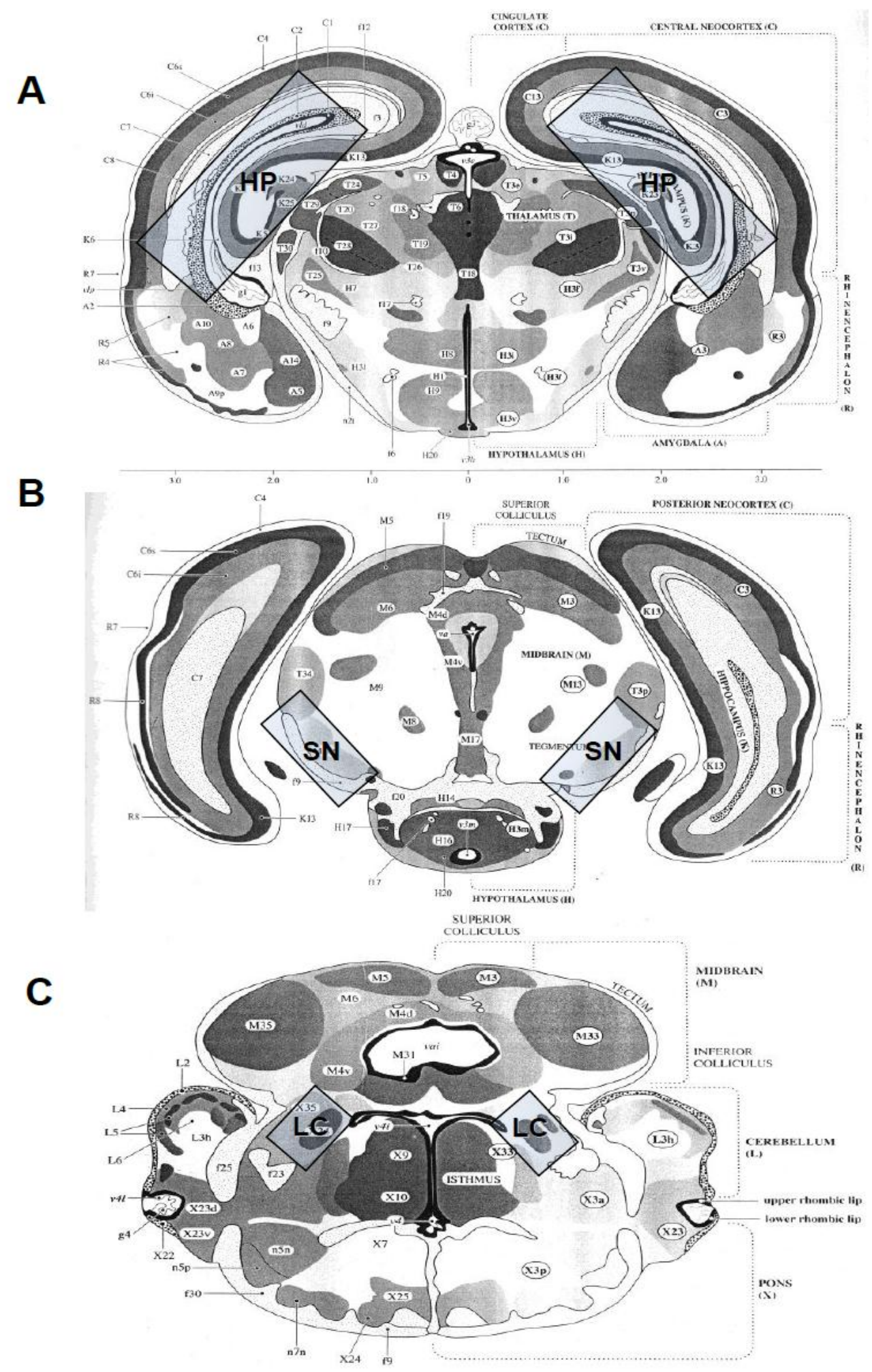

Figura 4.Imagens representativas de secções do encéfalo de rato neonato contendo as regiões dissecadas para a cultura de células. (A) hipocampo, (B)região ventrolateral do mesencéfalo contendo a substância negra (SN), (C) região dorsomedial da ponte contendo o locuscoeruleus (LC) (Altman e Bayer, 1995). 


\subsection{Tratamento com rotenona das células em cultura}

As células foram tratadas com DMSO a 0,01\% para controle ourotenona 8 dias após o plaqueamento. Foram feitos experimentos para verificação das curvas dose-resposta da modulação das proteínas motoras de mitocôndrias, KIF $1 \mathrm{~B} \alpha$ e KIF 5 através da técnica de Western Blot. A resposta dose-dependente foi verificada pela incubação das culturas por 48 horas com 0,1; 0,3 e 0,5 nM de rotenona. O fármaco foi preparado com DMSO (solvente da rotenona administrado a 0,01\%) e diluído em meio de cultura que foi aplicado sobre as células. Após o tempo destinado ao tratamento, as células foram lavadas e lisadas para a extração da proteína e Western Blot.

Esses experimentos foram repetidos pelo menos 3 vezes em culturas independentes para analisar possíveis variações biológicas, mas foram analisados em um mesmo momento para evitar variabilidade técnica.

\subsection{Extração de proteína e Western Blotting para análise das proteínas Rab e das proteínas motoras KIF 1B e KIF5}

As células em cultura e o tecido proveniente dos animais idosos foram lisados, homogeneizados utilizando-se $100 \mu$ de tampão de lise constituído de tergitol, deoxicolato de sódio, SDS, EDTA, EGTA e coquetel inibidor de proteases (Sigma) em PBS sem cálcio. Em tecido foi adicionado $250 \mu \mathrm{l}$ de tampão de lise, os fragmentos de tecido foram homogeneizados por força mecânica A quantidade de proteína foi acessada pelo método de Bradford (Bradford, 1976). A curva de calibração foi feita utilizando-se albumina em quantidade de 0 a $16 \mu \mathrm{g}$ de proteína por pocinho.

As amostras $(15 \mu \mathrm{g})$ foram desnaturadas à $100^{\circ} \mathrm{C}$ durante 3 minutos e em seguida centrifugadas, sendo a fração sobrenadante utilizada para análise das proteínasRab 1, 4, 5, 6, 11 e 32 e proteínas motoras KIF $1 \mathrm{~B} \alpha$ e KIF 5. As amostras foram aplicadas às canaletas do gel de poliacrilamida a $12 \%$ para fracionamento, em uma das canaletas foi aplicado o marcador de peso molecular (Kaleidoscope, Bio-Rad, EUA). O tampão de corrida foi preparado com trizma, glicina e SDS, as proteínas foram separadas através de aplicação de 100 volts durante cerca de 1 hora.

Após a corrida, as proteínasforam transferidas para membrana de nitrocelulose que foi bloqueada com leite $5 \%$ em TBS-T durante 1 hora à 
temperatura ambiente para as Rab 1, 4, 5, 6 e BSA 3\% em TBS-T 1 hora à temperatura ambiente para Rab 11, seguida da incubação dos seguintes anticorpos primários: anti-Rab1 (1/1000) (Santa Cruz sc-28566), anti-Rab4 (1/1000) (Santa Cruz 28569), anti-Rab5 (1/1000) (Santa Cruz 309), anti- Rab6 (1/1000) (Santa Cruz 310), anti-Rab11 (1/500) (Santa Cruz 26590). Para a diluição dos anticorpos primários foram usadas as seguintes soluções: leite $3 \%$ em TBS-T 1 hora à temperatura ambiente para Rab 1, Rab, 4, Rab 5 e Rab 6, BSA 1\% em TBS-T 1 hora à temperatura ambiente para Rab 11. O anticorpo secundário foi conjugado a uma peroxidase (HRP), a incubação da membrana com este anticorpo foi feita à temperatura ambiente durante 60 minutos. Sendo que para Rab 6 e Rab 11 foi utilizado anti-mouse (1/6000), para Rab 1, Rab 3, Rab 4, Rab 5 anti-rabbit (1/10000).

Para as proteínas motoras a membrana recebeu bloqueio de leite $5 \%$ e BSA $1 \%$ em TBS-T durante 1 hora à temperatura ambiente, seguida de incubação dos seguintes anticorpos primários: anti-KIF 1B (1/200) (KIF1B, Santa Cruz, SC-18739); anti-KIF 5 (1/500) (KIF5, Abcam, AB62104). Os anticorpos primários foram diluídos nas seguintes soluções: leite 3\% em TBS-T por 12 horas à $4^{\circ} \mathrm{C}$, e para anti-KIF 5 leite $3 \%$ e BSA $1 \%$ em TBS-T por 1 hora à temperatura ambiente.

O anticorpo secundário foi conjugado a uma peroxidase (HRP), a incubação da membrana com este anticorpo foi feita à temperatura ambiente durante 45 a 60 minutos. Sendo que para anti-KIF $1 \mathrm{~B} \alpha$ foi utilizado anti-goat (1/2000), para anti-KIF 5,anti-rabbit (1/10000).

As membranas foram então lavadas e a marcação foi revelada através de incubação com reagente quimioluminescente (Western EnhancingChemiluminescenceReagent Plus, ECL kit, Perkinelmer, EUA) durante 1 minuto e exposição a filme apropriado (Hyperfilm ECL, AmershamBiosciences) que foram revelados conforme instruções do fabricante.

Em seguida, as membranas foram submetidas a nova marcação com anticorpo contra a beta-actina (1/1000) (Santa Cruz) em leite $3 \% 1$ hora à temperatura ambiente, para normalização, seguida de incubação com 0 anticorpo secundário (anti-camundongo, 1/6000, conjugado a HRP, Amersham), reação e revelação como já descrito.

Os filmes foram quantificados usando o programa IMAGE J(NIH.) 


\subsection{Extração do RNA e PCR em tempo real}

O ambiente de trabalho foi limpo utilizando-se solução descontaminante de RNAse (RNAse ZAP, Ambion), também foram utilizados tubos, ponteiras e soluções livres de RNAses. Para a extração de RNA da cultura, utilizou-se kit e protocolo da empresa GE healthcare (RNAspin Mini). Já o RNA dos animais idosos foi extraído usando olnviTrap® Spin Tissue RNA Kit 1062100300 (Invitek Berlin).

Para acessar a quantidade e qualidade do RNA extraído, primeiramente uma amostra foi submetida a espectrofotômetro para ter a absorbância à UV determinada. As amostras que revelaram uma razão A260:A280 menor que 1,8 foram descartadas. Após a determinação da concentração de RNA, uma outra amostra contendo $1 \mu \mathrm{g}$ de RNA total e $1 \mu$ lde reagente BlueGreen (LGC) foi fracionada em gel de agarose $1 \%$. A proporção entre as frações $28 \mathrm{~S}$ e $18 \mathrm{~S}$ do RNA ribossômico deverá ser de aproximadamente 2:1 para que o RNA total seja considerado de boa qualidade e apropriado para as análises em PCR em tempo real.

O PCR em tempo real foi realizado utilizando-se o equipamento disponível no ICB do Departamento de Biologia Celular e do Desenvolvimento em colaboração com a Professora Dra. Edna Teruko Kimura.

O RNA foi transformado em cDNA, através de transcrição reversa, a fim possibilitar a reação de PCR em tempo real. Para tanto, a $1 \mu \mathrm{g}$ de RNA total foram adicionados tampão TaqMan, $\mathrm{MgCl}_{2}$, dNTPs, hexâmeros randômicos, inibidor de RNAse e a enzima transcriptase reversa atingindo o volume final de $50 \mu$ l, conforme instruções do fabricante (TaqMan - Applied Biosystems, EUA). Ao final do procedimento o cDNA foi estocado em freezer a $-80^{\circ} \mathrm{C}$ até sua utilização no PCR em tempo real.

Para análise dos RNAms das proteínas motoras foram utilizadas as seguintes sondas comercialmente disponíveis e seguindo-se estritamente 0 protocolo recomendado pelo fabricante (TaqMan - AppliedBiosystems, EUA), cujos códigos são os seguintes: KIF 1: Rn01639035 e KIF 5: Rn 01505190.Foram avaliados também os RNAms das proteínas Rab após tratamento com rotenonain vivo utilizando-se sondas comercialmente disponíveis 
e seguindo-se estritamente o protocolo recomendado pelo fabricante (TaqMan AppliedBiosystems, EUA), cujos códigos são os seguintes: Rab1: Rn00821241_g1,Rab 3: Rn00564615_m1, Rab4a: Rn00564621_m1, Rab5a: Rn00821140_g1, Rab6a: Rn01507612_m1, Rab11a: Rn00579853_m1, Rab32: Rn01766057_m1.

A normalização das reações foi feita utilizando primers e probe para RNA ribossômico (18S) (AppliedBiosystems, EUA). As soluções foram preparadas de acordo com as instruções do fabricante e colocadas em placa de 96 poços com qualidade óptica (ABI Prism, AppliedBiosystems, EUA) que será lacrada com adesivo também com qualidade óptica (ABI Prism, AppliedBiosystems, EUA) e submetida à amplificação em equipamento de PCR em tempo real (modelo 7300, ABI Prism, AppliedBiosystems, EUA) por 50 ciclos.

\subsection{Análise dos resultados}

Os resultados referentes aosanimais, foram avaliados por Anova de medidas repetidas para os testes de avaliação do peso e da atividade locomotora, eTeste-T para análise das proteínas e RNAms. Os resultados referente à dose-resposta foram avaliados por análise de variância de uma via (ANOVA) feita usando o programa estatístico GraphPad Prism para Windows (versão 4.03, 21 de janeiro de 2005, GraphPad Software, San Diego, Califórnia, USA). Foi considerada a margem de $5 \%(p \leq 0,05)$ para indicar diferenças significativas entre os grupos. 


\section{Resultados}




\subsection{Animais, tratamento com rotenona e comportamento}

Nenhum dos grupos analisados apresentou diferença significativa de peso ao longo das semanas de tratamento com rotenona. Revelando assim que a rotenona parece não ter efeito tóxico sistêmico refletido no peso dos animais ao longo do tratamento nas dosagens empregadas, de até $1 \mathrm{mg} / \mathrm{kg} / \mathrm{dia}$, padronizada anteriormente por não promover a formação de agregados proteicos.

O teste comportamental foi realizado sempre após a pesagem dos animais ao longo das semanas com o intuito de avaliar a atividade locomotora. Foi observado que a concentração de rotenona utilizada não provocou efeitos tóxicos a ponto de provocar déficit motor (Figura 5). 

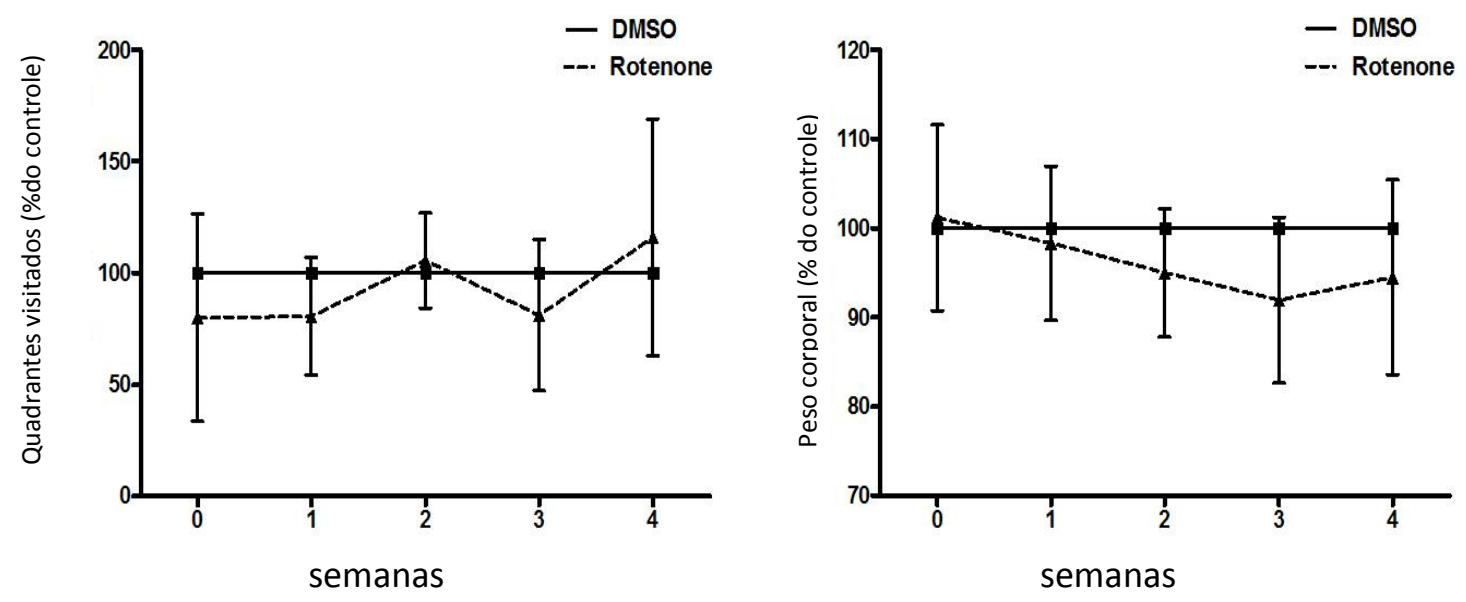

FIGURA 5.Variação semanal do peso e comportamento dos 10 ratos (\% DMSO e 5 rotenona) submetidos a exposição com DMSO:PEG ("Controle", linha contínua) e a $1 \mathrm{mg} / \mathrm{kg} / \mathrm{dia}$ de rotenona ("Rotenona 1", linha tracejada) infundidos subcutaneamente durante 4 semanas de tratamento. Os valores são apresentados como média \pm desvio padrão, segundo $\circ$ a análise de variância de medidas repetidas. 


\subsection{Análise da expressão das proteínas Rab em ratos idosos}

$\mathrm{Na}$ região do hipocampo foi observado aumento da expressão proteica das Rab 4, 5 e 6, enquanto os níveis de Rab 1 diminuíram e os níveis relacionados a expressão da Rab 11 não se alteraram. Já os níveis de expressão gênica aumentaram para as Rab 1, 6 e 11, e diminuíram para as Rab 4 e 5 (Figura 6).

Na substância negra, uma das primeiras e principais regiões afetadas na doença de Parkinson, houve aumento dos níveis de expressão da proteína Rab 1 e diminuição da Rab 6, enquanto a expressão das Rab 4, 5 e 11 permaneceram inalterados. E os níveis de expressão gênica das Rab 1 e 4 aumentaram, e os níveis de expressão gênica das Rab 5, 6 e 11 diminuíram (figura 7) .

No locus coeruleus de ratos idosos foi observado diminuição nos níveis de expressão das proteínas Rab 1 e 5 , mas a Rab 6 está aumentada apósexposição à rotenona e a Rab 4 e 11 não se alteram. Já os níveis de expressão gênica revelaram aumento dos níveis das Rab 4 e 6, enquanto os níveis de expressão da Rab 5 e 11 diminuíram, após o tratamento com rotenona (Figura 8).

A expressão gênica das Rab 3 e 32 foi analisada nas três regiões propostas, sendo observado aumento da expressão gênica da Rab 3 na região da substância, e aumento também dos níveis de Rab 32 na substância negra e locus coeruleus, enquanto que na região do hipocampo os níveis de Rab 32 diminuíram, e de Rab 3 permaneceram inalterados, assim como no locus coeruleus (Figura 9). 


\section{Hipocampo}
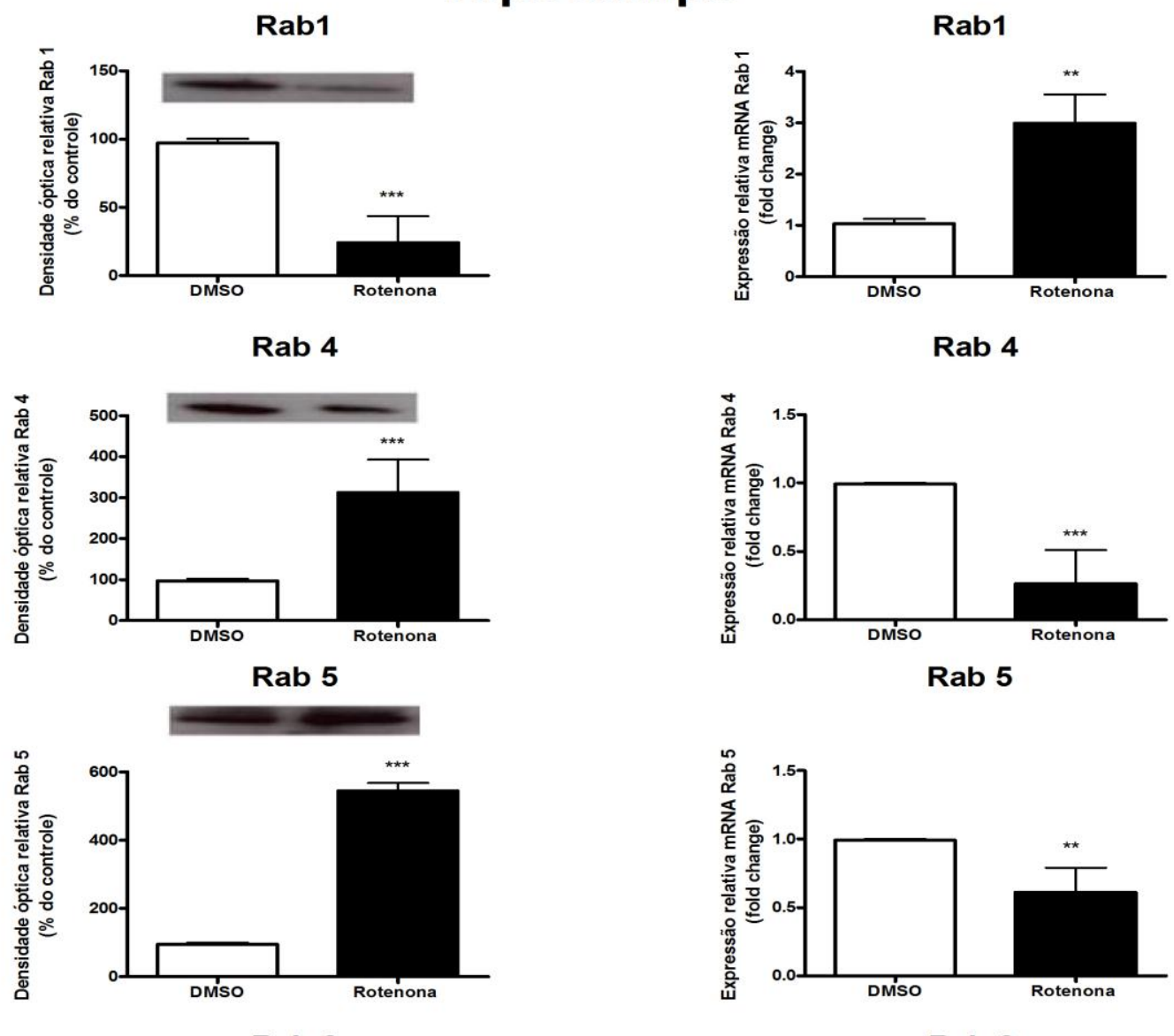

Rab 6

Rab 6
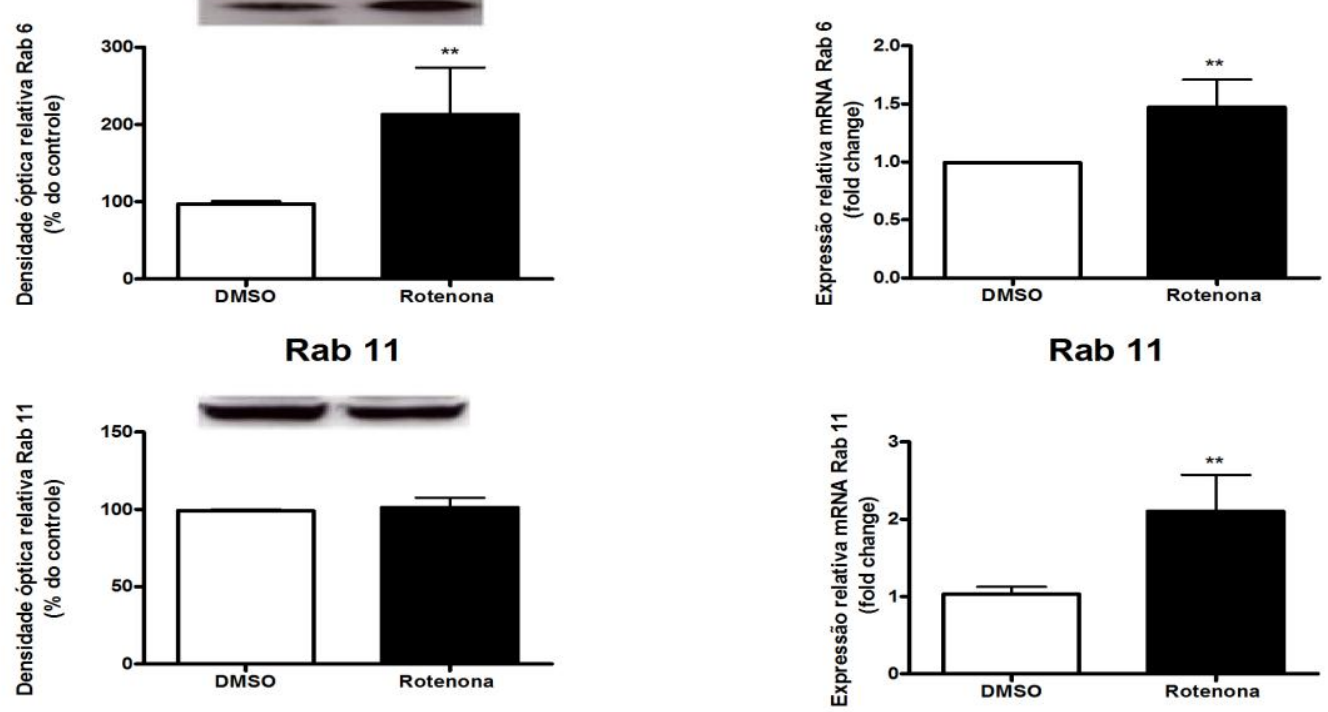

Figura 6.Expressão proteica e gênica das proteínas Rab 1, 4, 5, 6 e 11 no hipocampo de 10 ratos Lewis idosos tratados com DMSO (5 animais) ou rotenona $1 \mathrm{mg} / \mathrm{kg} / \mathrm{dia}$ (5 animais) durante 1 mês. Os valores são expressos como média \pm desvio padrão, em porcentagem comparado com o controle, segundo o teste T de Student. ${ }^{*} p<0,05$. 


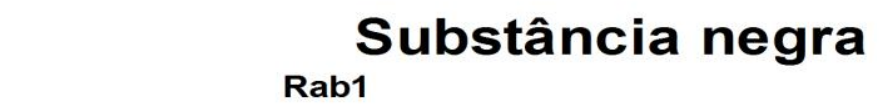

Rab1
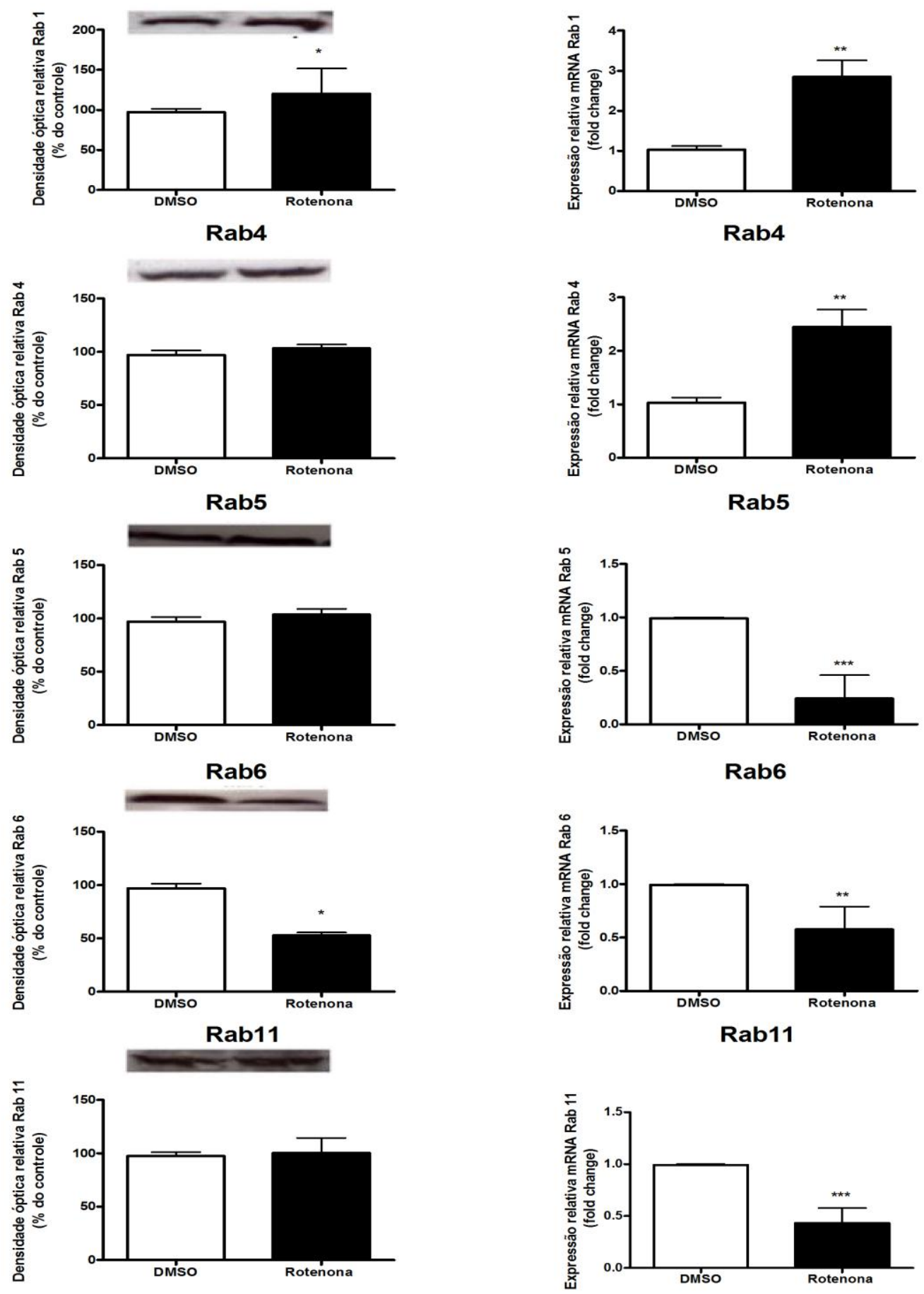

Figura 7.Expressão proteica e gênica das proteínas Rab 1, 4, 5, 6 e 11 na substância negra de 10 ratos Lewis idosos tratados com DMSO (5 animais) ou rotenona $1 \mathrm{mg} / \mathrm{kg} /$ dia (5 animais) durante 1 mês. Os valores são expressos como média \pm desvio padrão, em porcentagem comparado com o controle, segundo o teste $\mathrm{T}$ de Student. ${ }^{*}<0,05$ 


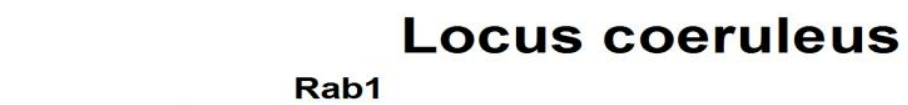

Rab1
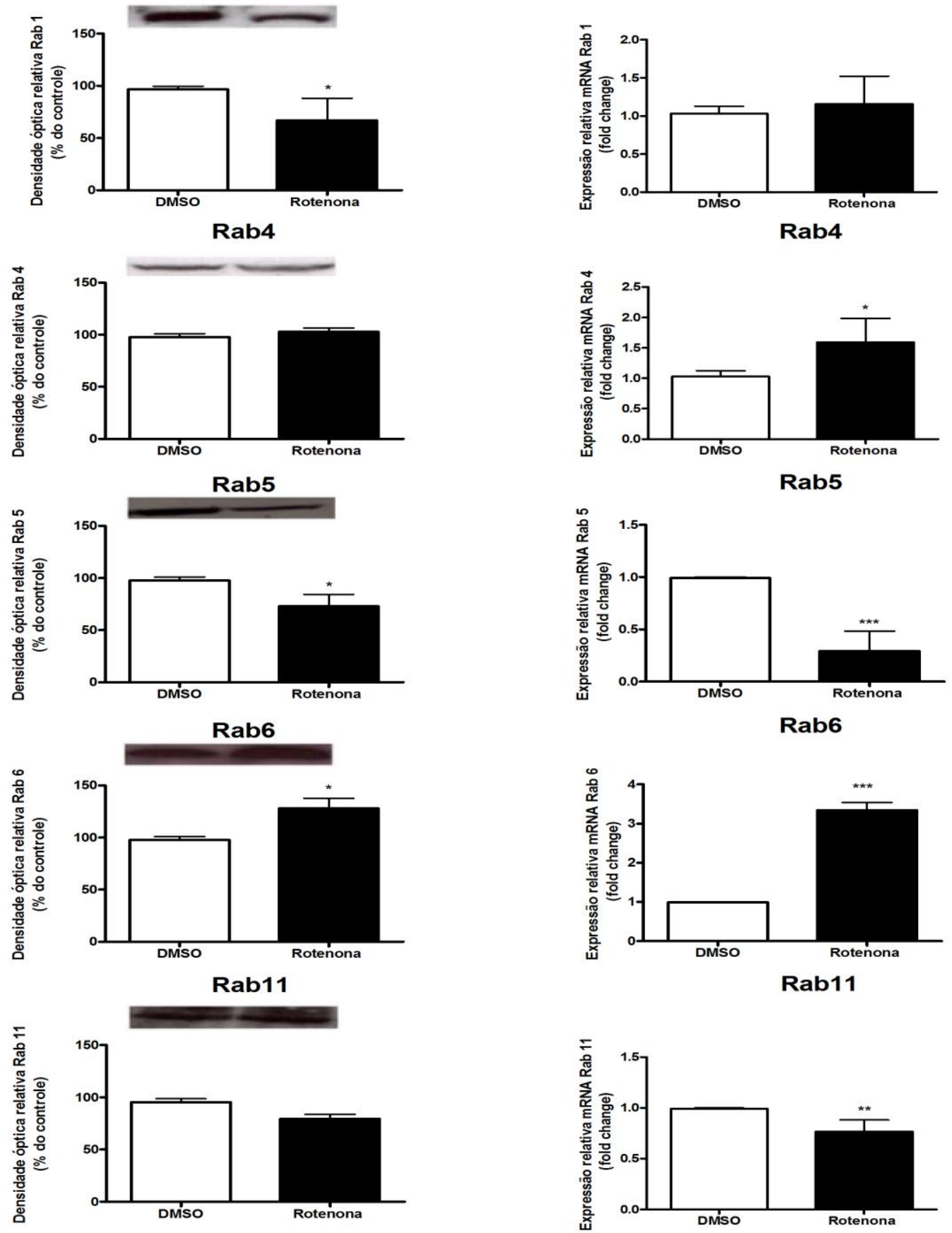

Figura 8.Expressão proteica e gênica das proteínas Rab 1, 4, 5, 6 e 11 no locuscoeruleus de 10 ratos Lewis idosos tratados com DMSO (5 animais) ou rotenona $1 \mathrm{mg} / \mathrm{kg} /$ dia (5 animais) durante 1 mês. Os valores são expressos como média \pm desvio padrão, em porcentagem comparado com o controle, segundo o teste $\mathrm{T}$ de Student. ${ }^{*} p<0,05$ 


\section{Rab3}
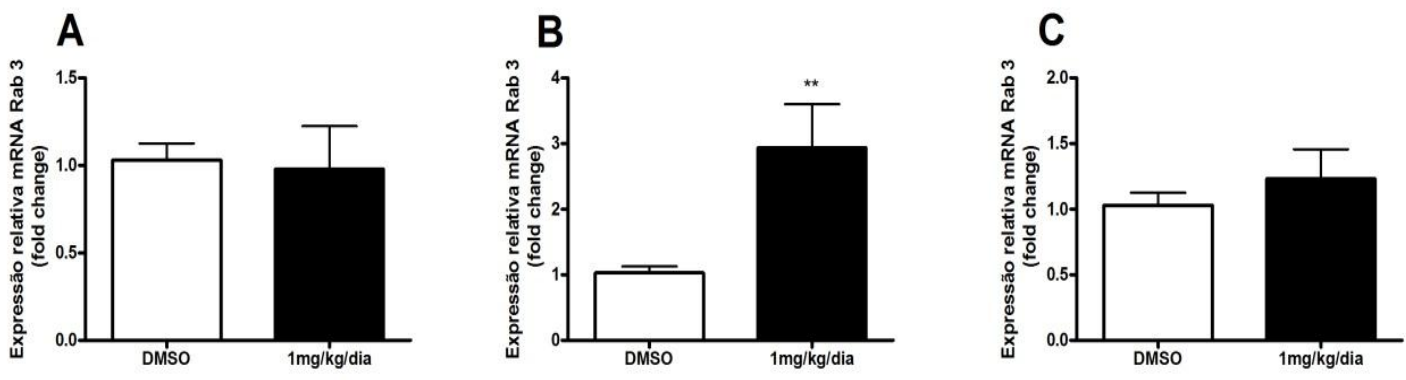

Rab 32
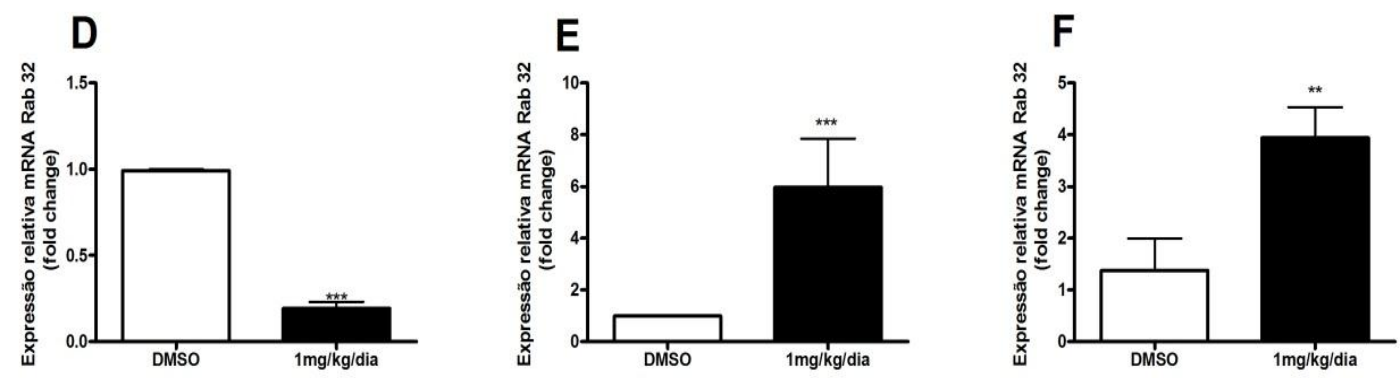

Figura 9.Expressão gênica dasRab3 e 32 no hipocampo (A e D respectivamente), na substância negra ( $B$ e $E$ respectivamente) e locus coeruleus ( $C$ e $F$ respectivamente) de 10 ratos Lewis idosos tratados com DMSO (5 animais) ou rotenona $1 \mathrm{mg} / \mathrm{kg} / \mathrm{dia}$ (5 animais) durante 1 mês. Os valores são expressos como média \pm desvio padrão, em porcentagem comparado com o controle, segundo o teste T de Student. ${ }^{*} p<0,05$ 
4.3. Análise da expressão das proteínas motoras relacionadas ao transporte anterógrado em cultura de células

Em culturas de células da região do hipocampo foi observado que não houve alteração da expressão das KIF 1(Figura 9 A e B) e KIF 5 (Figura 9 C e D) para os tratamentos dose-dependente e tempo-dependente. 


\section{Hipocampo}

\section{KIF 1B}
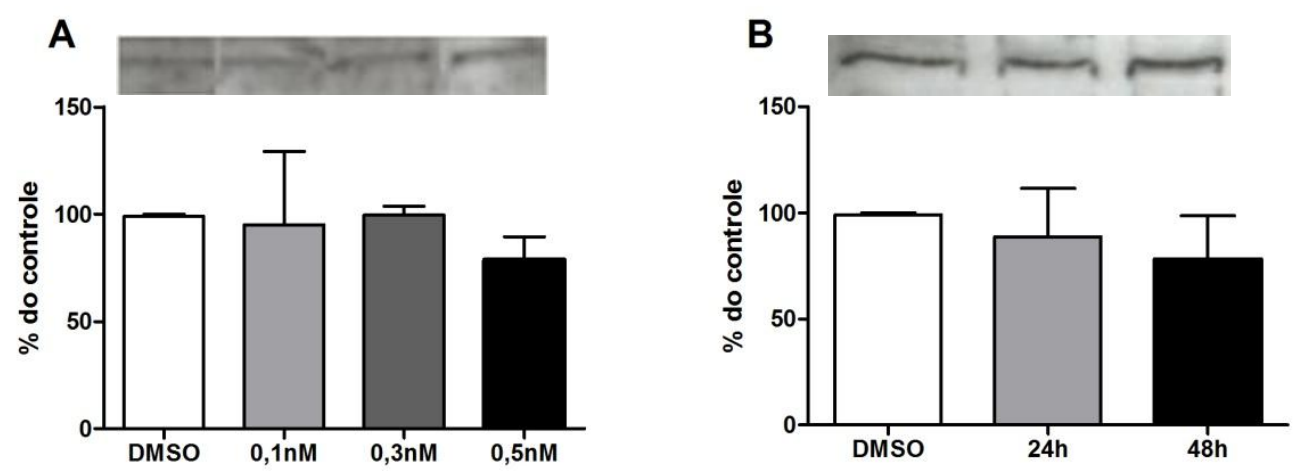

\section{KIF 5}
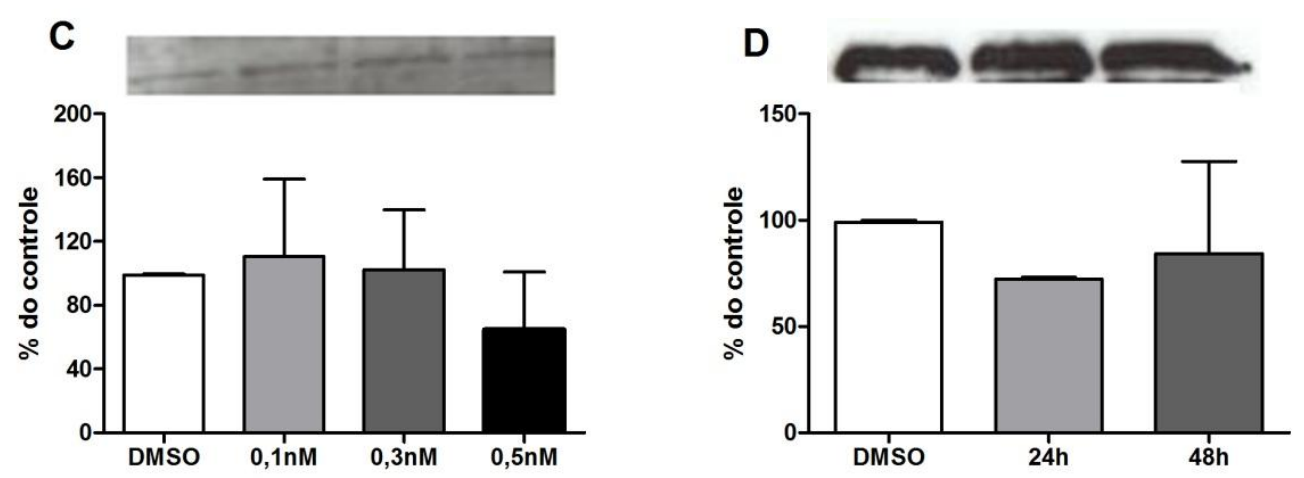

Figura 10. Expressão da KIF 1 e 5 em culturas de células do hipocampo expostas a DMSO ou rotenona nas concentrações de $0,1 \mathrm{nM}, 0,3 \mathrm{nM}$ ou $0,5 \mathrm{nM}$ por 48 horas(A e C), ou rotenona na concentração de $0,3 \mathrm{nM}$ por 24 horas ou 48 horas (B e D). Os valores são expressos em porcentagem do controle \pm desvio padrão, e analisados por ANOVA de uma via. 
A cultura de células da região da substância negra mostrou um aumento de expressão da KIF 1B após o tratamento com 0,5nM de rotenona durante 48 horas, comparado com DMSO e outros tratamentos (Figura 10A). Com o tratamento tempo-dependente houve uma diminuição da expressão da proteína após a exposição com $0,3 \mathrm{nM}$ por 24 horas comparado com o controle (Figura 10B).

Análises da expressão da KIF 5 mostrou uma diminuição da expressão da proteína motora após o tratamento com $0,1 \mathrm{nM}$ de rotenona por 48 horas comparado com o controle, e um aumento com o tratamento de $0,5 \mathrm{nM}$ de rotenona por 48 horas, comparado com o controle e outros tratamentos (Figura 10C). Mas para a exposição a $0,3 n M$ de rotenona por 24 horas observou-se uma diminuição na expressão da proteína comparado com o controle, o que foi revertido após 48 horas (Figura 10D). 


\section{Substância negra}

\section{KIF 1B}
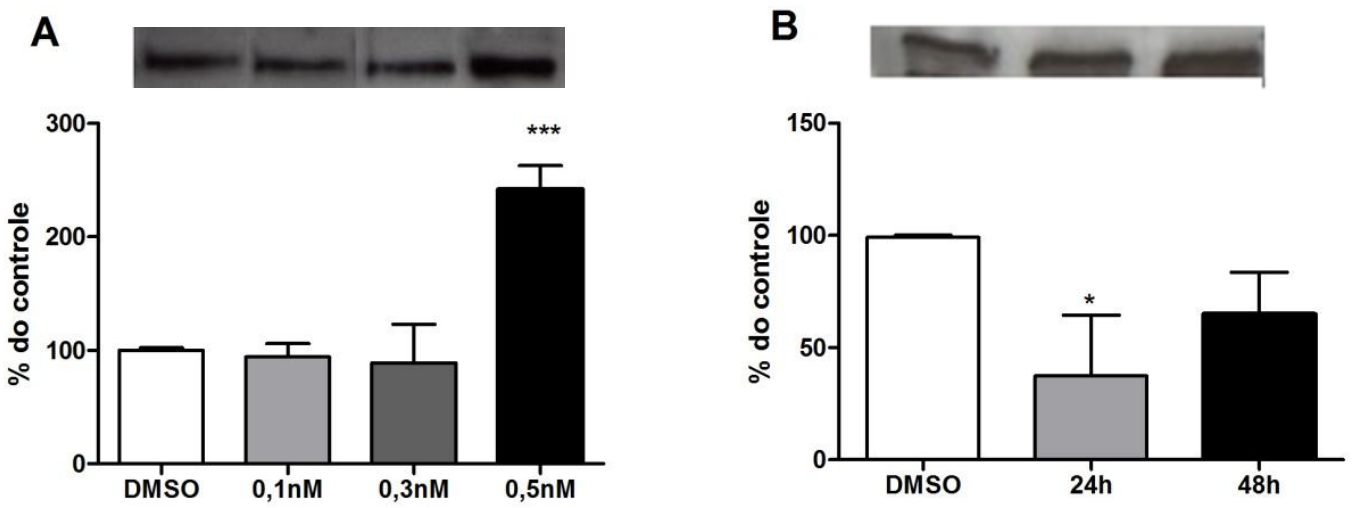

\section{KIF 5}
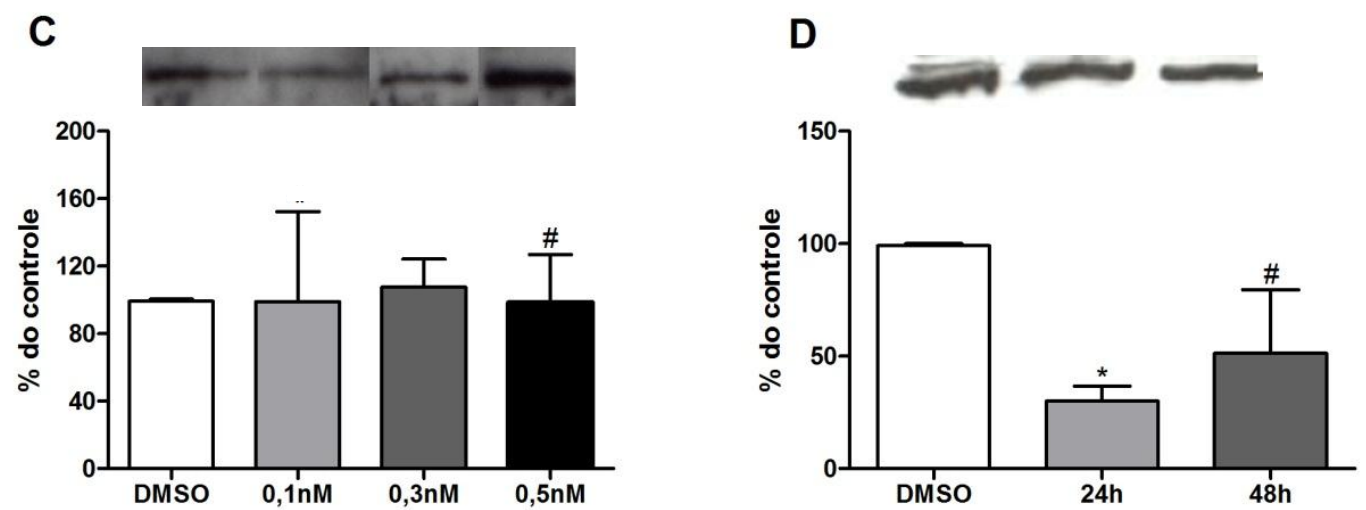

Figura 11. Expressão da KIF 1 e 5 em culturas de células da substância negra expostas a DMSO ou rotenona nas concentrações de $0,1 \mathrm{nM}, 0,3 \mathrm{nM}$ ou $0,5 \mathrm{nM}$ por 48 horas (A e C), ou rotenona na concentração de $0,3 \mathrm{nM}$ por 24 horas ou 48 horas (B e D). Os valores são expressos em porcentagem do controle \pm desvio padrão, e analisados por ANOVA de uma via 
A KIF 1B não se alterou em células do Locus coeruleus com o tratamento com rotenona (Figura 11 A e B). Já a KIF 5 aumentou após exposição a rotenona a $0,1 \mathrm{nM}$ por 48 horas, quando comparado com DMSO e outras doses de rotenona. Foi observado uma diminuição na expressão proteica com o tratamento de $0,3 \mathrm{nM}$ de rotenona comparado com os tratamentos de $0,1 \mathrm{nM}$ por 48 horas. Além disso a exposição a rotenona por 48 horas a $0,5 \mathrm{nM}$ promoveu diminuição na expressão quando comparado com o controle e com os demais tratamentos (Figura $11 \mathrm{C}$ ). A expressão da KIF 5 não variou com o tempo de exposição à rotenona (Figura $11 \mathrm{D})$. 


\section{Locus Coeruleus}

\section{KIF 1B}

\section{A}

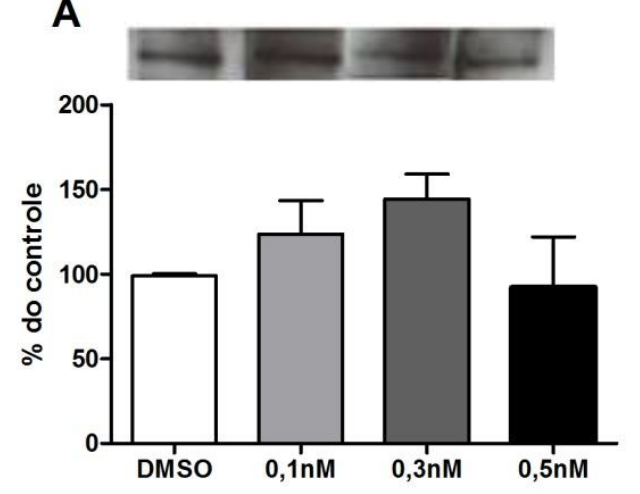

B

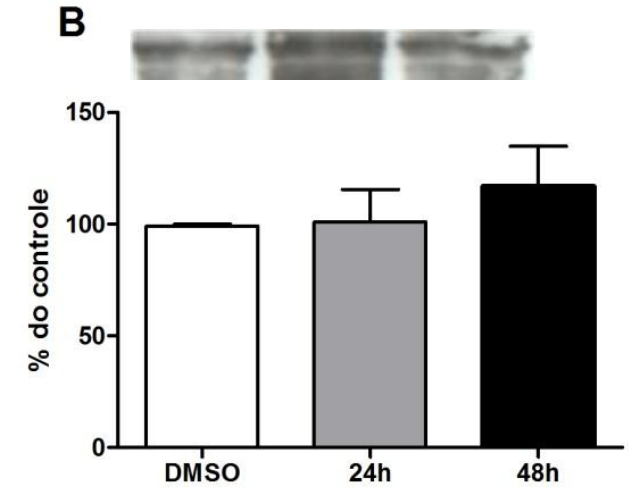

\section{KIF 5}
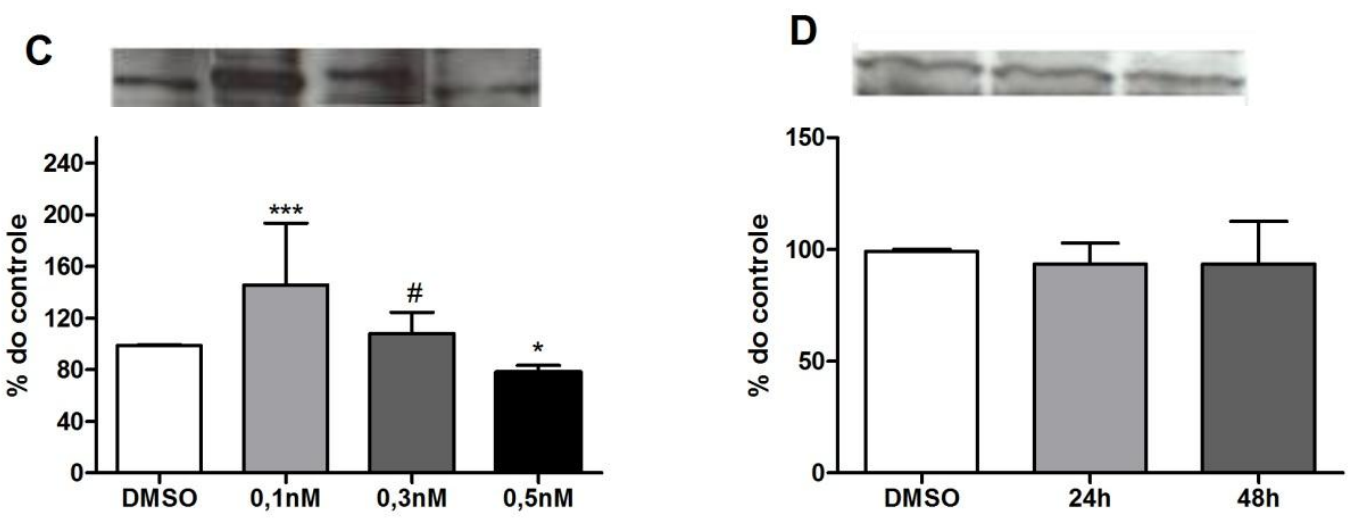

Figura 12. Expressão da KIF 1 e 5 em culturas de células do locus coeruleus expostas a DMSO ou rotenona nas concentrações de $0,1 \mathrm{nM}, 0,3 \mathrm{nM}$ ou $0,5 \mathrm{nM}$ por 48 horas(A e C), ou rotenona na concentração de $0,3 \mathrm{nM}$ por 24 horas ou 48 horas (B e D). Os valores são expressos em porcentagem do controle \pm desvio padrão, e analisados por ANOVA de uma via 
5.Discussão 
A rotenona causa inibição do complexo I da cadeia transportadora de elétrons. Alguns estudos relacionam estresse oxidativo com distúrbios no tráfego e doenças neurodegenerativas, mostrando prejuízo das funções dos complexos mitocondriais e causando superprodução de espécies reativas de oxigênio, que estão presentes nos estágios tardios de doenças neurodegenerativas (Guidetti et al., 2001).

Os efeitos tóxicos da rotenona em ratos e em cultura de células, especialmente sobre as regiões encefálicas analisadas no presente estudo, são bem conhecidos. No entanto, resultados anteriores do laboratório, estabeleceram um modelo de neurodegeneração envolvendo agregação de proteínas após administração de baixas concentrações de rotenona(Chaves et al., 2010).

Naquele estudo foram observados acúmulos de alfa-sinucleína, tau hiperfosforilada e beta amiloide, as quais estão associadas à doença de Alzheimer e Parkinson, com o uso de rotenona nas concentrações de 0,5nM e $1 \mathrm{nM}$ nas células em cultura (Chaves et al., 2010). As mesmas proteínas se agregam nos cérebros de ratos idosos expostos a $2 \mathrm{mg} / \mathrm{kg} / \mathrm{dia}$ de rotenona. Com isso, as concentrações utilizadas no presente estudo permitem analisar a expressão de proteínas do tráfego antes e concomitante à agregação proteica.

Atualmente novos estudos já mostraram os efeitos intrínsecos da rotenona nas células, especialmente nos neurônios, onde a rotenona age diminuindo a atividade da enzima da via glicolítica gliceraldeído-3-fosfato desidrogenase (GAPDH) (Huang et al., 2011). A disfunção da GAPDH é um evento importante da morte de células em doenças neurodegenerativas (Chuang et al., 2005);(Shalova et al., 2007) bem como está envolvida no processo geral de envelhecimento (Ishitani e Chuang, 1996).

Sabe-se que alterações no tráfego podem conduzir a agregação de proteínas e consequente neurodegeneração(Cavalli et al., 2005). Por isso, o presente estudo objetivou a análise da expressão das proteínas Rab e das cinesinas com o uso de concentrações de rotenona que não chegam a formar agregação proteica. 
Com relação aos níveis de Rab1, foi observado aumento da expressão desta proteína na substância negra, o que pode revelar um mecanismo preventivo à toxicidade que a célula está exposta, apesar de ainda não haver acúmulo de proteínas.Enquanto que no locuscoeruleus, cujos neurônios são mais susceptíveis a mudanças que conduzem a neurodegeneração(Arendt et al., 1995), a Rab1 encontra-se diminuída, assim como na região do hipocampo, demonstrando uma maior suscetibilidade dessa região também.

Como já mencionado, a Rab1 participa do tráfego de vesículas entre o retículo endoplasmático e o complexo de Golgi. Em experimentos que superexpressaram a alfa-sinucleína em levedura, o tráfego de vesículas entre o retículo endoplasmático e o complexo de Golgi, assim como o ancoramento ou fusão das vesículas nas membranas do Golgi, foram prejudicados, mas a presença da Rab 1 reverteu esse quadro, demonstrando que essa GTPase atenua a toxicidade da alfa-sinucleína nos neurônios dopaminérgicos em conjunto com a Rab 3, em modelos animais da doença de Parkinson e in vitro(Cooper et al., 2006).

A co-expressão da Rab 1 com a alfa-sinucleína evita a perda neuronal, assim como suprime os efeitos tóxicos da proteína agregada (Auluck et al., 2002). Contudo a alfa-sinucleína parece ter um papel regulatório fisiológico no tráfego de vesículas sinápticas. Células do hipocampo de camundongos nocauteados para alfa-sinucleína apresentam diminuição da reserva de vesículas sinápticas assim como de seu ancoramento (Cabin et al., 2002), mas a superexpressão da alfa-sinucleína resulta em aumento de vesículas ancoradas na região pré-sináptica (Larsen et al., 2006).

Os níveis dos RNA mensageiros da Rab 1 no hipocampo e na substância negra aumentaram, revelando que antes da formação de agregados a célula pode ter um mecanismo de proteção contra a toxicidade causada pela rotenona, que pode levar a formação dos agregados proteicos. O mesmo não se observa no locuscoeruleus, onde os níveis de expressão gênica permaneceram inalterados.

Em casos de acúmulo de vesículas como consequência da expressão de altos níveis de alfa-sinucleína, foi demonstrado a colocalização das proteínas Rab com vesículas agregadas e com a alfa-sinucleína, sugerindo que a alfasinucleína possa sequestrar as proteínas Rab de seus alvos normais de 
membrana, o que pode resultar em uma deficiência generalizada do tráfego inter-organelas(Soper et al., 2011), além de inibir a exocitose e a reciclagem de vesículas sinápticas nos neurônios de mamíferos(Nemani et al., 2010, Scott etal., 2010), e prejudicar a exocitose(Kuwaharaet al., 2008).

A toxicidade da alfa-sinucleína também pode estar em interferir indiretamente no metabolismo da dopamina, uma vez que a inibição do tráfego das vesículas contendo o neurotransmissor provoca o acúmulo intracelular dessas vesículas, o que é potencialmente tóxico podendo causar degeneração seletiva nos neurônios da substância negra (Xu et al., 2002).

No presente estudo não foram observadas diferenças na expressão da proteína Rab 4, tanto na substância negra quanto no locus coeruleus, enquanto no hipocampo os níveis da proteína subiram. A Rab4 está envolvida com o tráfego de vesículas importantes para a sobrevivência neuronal, como o fator de crescimento neural (NGF) (Novick e Brennwald, 1993). Nesse caso tanto a Rab 4 quanto a Rab5 são responsáveis por regular o tráfego retrógrado endossomal, e o material pode ser reciclado e voltar para superfície da membrana via proteínas Rab 4 e 11(Schmidt e Haucke, 2007).

O NGF é transportado retrogradamente a partir dos terminais nervosos via endossomos (Delcroix et al., 2003, Ye et al., 2003), para o corpo celular onde possui um importante papel na célula neural durante o desenvolvimento do sistema nervoso, assim como na vida adulta promovendo o crescimento dos cones axonais e permitindo a viabilidade da célula nervosa. Esse tráfego retrógrado é mediado em parte pelas proteínas Rab 4, 5 e 11 que também participam da endocitose e de processos autofagocitose. É interessante notar que durante a neurodegeneração a via autofagocítica está ativada e associada à degradação dos agregados (Butler et al., 2005, Bronfman et al., 2007) inclusive com a participação das Rab 4, 5 e 11 (Kaasinen et al., 2008). Considerando que haja uma demanda elevada de proteínas responsáveis pela autofagocitose, pode-se especular que isso acarrete em redução na disponibilidade de proteínas para formação do endossomo(Kaasinen et al., 2008).

No presente estudo, como não há agregação proteica, os eventos de autofagocitose nas regiões da substância negra e locuscoeruleus não sequestrariam a Rab 4 mantendo seus níveis basais necessários aos processos celulares. Porém na região do hipocampo o tratamento foi efetivo para aumentar 
os níveis proteicos e gênicos nas regiões da substância negra e locus coeruleus, o que pode demonstrar uma ação preventiva a neurodegeneração na região do hipocampo, evitando assim um desbalanço da via endocítica antes da formação das inclusões proteicas. Os níveis de expressão gênica na substância negra e locus coeruleus aumentaram, o que pode ser uma preparação da célula para evitar modificações na via endocítica na presença dos agregados proteicos, o mesmo não ocorre no hipocampo, onde os níveis de RNA mensageiros encontram-se diminuídos em relação ao controle, demonstrando que talvez na presença dos agregados essa região esteja vulnerável aos mecanismos que podem desencadear a disfunção endocítica.

Nesse estudo não houve diferença nos níveis de expressão da Rab 5 na substância negra dos ratos idosos após exposição à rotenona, demonstrando que essa via não parece ser alterada pelo tratamento realizado. Já no locus coeruleus a expressão da Rab 5 diminuiu após exposição à rotenona, o que sugere que talvez nessa região a via endocítica possa já estar comprometida antes do aparecimento de proteínas agregadas características de doenças neurodegenerativas.

Dhani e colaboradores (2008) demonstraram que o déficit energético celular promovido pela redução dos níveis de ATP produzidos pela mitocôndria podem levar a prejuízo das vias endocítica e de reciclagem pela diminuição da atividade das proteínas Rab 11 e 5 nos neurônios

Por outro lado, dados recentes mostram que em neurônios corticais, a internalização da beta-amiloide é acompanhada pelo aumento dos níveis de GTPases como a Rab 5, que é marcadora de endossomo, além de ocorrer mudanças em sua distribuição (Song et al., 2011), que conduz à toxicidade neuronal por causa da alteração no sistema endossoma e lisossomo, o qual é prejudicado durante o metabolismo da beta-amiloide(Nixon, 2005).

No hipocampo observamos um aumento dos níveis proteicos, o que pode revelar sensibilidade da região aos mecanismos que conduzem a neurodegeneração. Porém os níveis de expressão gênica nas regiões do hipocampo, substância negra e locus coeruleus encontram-se diminuídos , lembrando que a alfa-sinucleína é internalizada na célula via endocitose mediada pela Rab5, talvez a diminuição dos RNA mensageiros confira uma proteção da célula contra a toxicidade dos agregados extracelulares. 
Os endossomos primários medeiam a internalização endocítica, reciclagem e modulação catabólica de moléculas necessárias para a manutenção celular. Camundongos transgênicos e cérebros de pacientes com doença de Alzheimer têm aumento de beta-amiloide intracelular antes das deposições extracelulares extracelulares(Nagele et al., 2002, Gouras et al., 2005, Oddo et al., 2006). Esse peptídeo é internalizado via a Rab 5 que contribui para a degeneração neuronal, sendo que o bloqueio da internalização de betaamiloide previne a neurotoxicidade do peptídeo e a neurodegeneração(Song et al., 2011).

O aumento da expressão de Rab 5 é uma característica da patologia dos endossomos primários que além de mediar a captura da beta-amiloide, também servem de sítio de produção de beta-amiloide (Nixon, 2005). Desta forma, a diminuição da expressão da Rab 5 demonstrada nesse estudo na região do locuscoeruleus sugere que a via endocítica possa estar alterada, porém a internalização de fatores que contribuem para neurodegeneração pode estar inibida.

Para que haja formação de beta-amiloide, é necessário que a proteína precursora amiloide primeiro seja clivada pela beta-secretase e então pela gama-secretase(Sisodia e St George-Hyslop, 2002). A gama-secretase é um complexo composto de 4 componentes, incluindo a presenilina 1 (Haass, 2004). Tanto a proteína precursora amiloide como a presenilina 1, são proteínas transmembrana e a localização intracelular delas é controlada pelas vias secretória e endocítica.

A produção de beta-amiloide pode acontecer em uma ampla gama de compartimentos celulares como na superfície celular, rede trans-Golgi e nos endossomos(De Strooper, 2000), bem como pode ser consequência de um processo inflamatório característico da doença de Alzheimer, com a participação da prostaglandina E2 e seu receptor EP4 (Shinohara et al., 2010).

$O$ receptor EP4 interage com a presenilina 1 modulando sua endocitose. Logo o processo inflamatório favorece a formação de beta-amiloide, mas na presença de Rab 5 esse quadro é revertido nos neurônios(Shinohara et al., 2010), pois a prostaglandina é inibida, diminuindo a atividade da gamasecretase, e consequentemente a produção de beta-amiloide (Hoshino et al., 2009). Nesse trabalho os níveis de Rab 5 parecem não favorecer a possível 
recaptura da beta-amiloide, e ao mesmo tempo esses baixos níveis podem contribuir para produção do peptídeo beta-amiloide intracelularmente, além de também contribuírem para prejudicar a manutenção de endossomos gerais que estão ligados a outras funções neuronais como reciclagem de vesículas sinápticas

Postula-se a hipótese de que as vesículas sinápticas devem sofrer um processo de maturação para tornarem-se funcionais no terminal sináptico(Bonanomi et al., 2006). A Rab 5 está envolvida na via de maturação das vesículas que se dirigem aos terminais nervosos e encontra-se acoplada aos compartimentos endossomais(Fischer von Mollard et al., 1994). As vesículas endocíticas sinaptossomais podem também se fundir com os endossomos primários(Rizzoli et al., 2006). Em junções neuromusculares de Drosophila e células do hipocampo, foi visto que a Rab 5 está envolvida na manutenção endossomal para integridade da sinapse, pois foi observado que em neurônios de $C$. elegans a superexpressão da Rab 5 suprimiu o déficit na sinapse(Brown et al., 2009).

Em contraposição com a Rab 5, a expressão da Rab 6 encontra-se com suas expressões gênicas e proteicas diminuídas na substância negra após exposição à rotenona, sugerindo que antes da presença dos agregados proteicos o tráfego entre o retículo endoplasmático e o Golgi pode estar deficitário, porém já foi visto que os níveis de Rab 6 aumentaram antes do aparecimento de neurofilamentos contendo tau hiperfosforilada(Gonatas et al., 2006), talvez a baixa expressão da proteína observada nesse estudo pode ser um mecanismo protetor que antecede a neurodegeneração.

Entretanto no locus coeruleus e no hipocampo a expressão proteica e gênica da Rab 6 aumentaram em relação ao controle. Embora a maquinaria de formação da beta-amiloide aconteça especialmente nos dendritos, o processamento anormal do peptídeo afeta componentes sinápticos e altera a transmissão sináptica (Almeida et al., 2005), já foi observado que a proteína Rab 6 encontra-se acumulada e localizada dentro dos neuritos em camundongos modelo para doença de Alzheimer (Pierce et al., 2001), além de estar em níveis elevados no córtex nos casos de doença de Alzheimer (Mercer et al., 2008), assim como a Rab 5 que encontra-se em altos níveis, porém acumulada nos terminais pré-sinápticos (Brown et al., 2009). Se alteração da proteína Rab 6, é 
acompanhada de alteração na proteína Rab 5, provavelmente a proteína Rab 6 é mais suscetível aos fatores que levam a neurodegeneração, como injúrias nos complexos mitocondriais, podendo ser uma proteína marcadora de processos neurodegenerativos, uma vez encontrou-se alterada tanto na substância negra como no locus coeruleus em nosso trabalho.

Muito embora a expressão da proteína Rab 11 não tenha alterado sua expressão proteica no hipocampo, nem na substância negra, sua localização celular pode influenciar sua função, sendo que os momentos celulares que antecedem a neurodegeneração podem estar associados com acúmulo de Rab 11 sem alteração dos níveis de expressão dessa proteína. Porém seus níveis de expressão gênica no hipocampo encontram-se aumentados, o que sugere que num próximo momento celular, na presença de agregados proteicos pode haver acúmulo de Rab 11 nessa região.

Ainda com relação aos acúmulos de proteínas intracelulares, trabalhos anteriores mostraram que não apenas inclusões intracelulares de alfa-sinucleína são tóxicas para as células, mas acúmulos extracelulares dessa proteína, tanto monomérica como na forma de oligômeros, são neurotóxicos por ativarem micróglia e a astroglia (Klegeris et al., 2008), levando a liberação de substâncias pró-inflamatórias e consequente produção de espécies reativas de oxigênio especialmente nos neurônios dopaminérgicos, favorecendo a formação dos corpúsculos de Lewy(Kordower et al., 2008). Algumas hipóteses sugerem que a maior parte de alfa-sinucleína no meio extracelular provenha do citoplasma, a proteína seria liberada para o meio extracelular, podendo ser recapturada por neurônios e células gliais causando diversos efeitos biológicos (Forloni et al., 2000, Zhang et al., 2005).

A proteína Rab 11 parece ter um papel importante na via pós recaptura da alfa-sinucleína extracelular, na reciclagem dos endossomos e regulando a exocitose da alfa-sinucleína (Liu et al., 2009). Parece que a Rab 11 pode interagir diretamente ou indiretamente com as proteínas endocitadas, pois essa proteína já foi encontrada colocalizada com a alfa-sinucleína em situações fisiológica e patológicas onde pode inclusive contribuir para formação dos corpúsculos de Lewy(Liu et al., 2009).

A alfa-sinucleína é uma proteína que se agrega nos casos de doença de Parkinson hereditária ou esporádica, e em ambos os casos já foi encontrada 
associada a vesículas sinápticas em modelos in vivo e in vitro (Fortin et al., 2004, Kubo et al., 2005). Altos níveis de expressão da alfa-sinucleína resultam primariamente em bloqueio do tráfego de vesículas (Cooper et al., 2006, Gitler et al., 2008) e secundariamente em produção de espécies reativas de oxigênio (Outeiro e Lindquist, 2003).

A Rab 11 também participa da reciclagem de transportadores de cisteína (EAAC1) para a membrana neuronal. Esses transportadores são essenciais para a proteção celular contra danos oxidativos pela glutationa peroxidase. Esta enzima transforma a glutationa (GSH) em glutationa oxidada (GSSH), sendo a principal via antioxidante do cérebro (Dringen, 2000), essencial para proteger os constituintes celulares contra os danos causados pelas espécies reativas de oxigênio (Ballatori et al., 2009). Para que isso aconteça é necessária a presença de cisteína a qual é capturada através dos transportadores EAAC1. No entanto em situações em que os níveis de espécies reativas de oxigênio encontram-se elevados a reciclagem desse transportador fica comprometida, o que parece acontecer por conta da deficiência da proteína Rab 11. Li e colaboradores(Li et al., 2010) demonstraram que a superexpressão da Rab11 em neurônios corticais elevam os níveis de GSH intracelular prevenindo a morte neuronal.

Os níveis de expressão gênica da Rab 11 na substância negra e locus coeruleus encontram-se diminuídos, e levando em conta o estresse oxidativo ocasionado pela exposição a rotenona, a diminuição do RNA mensageiro pode refletir uma possível diminuição da proteína concomitante ao acúmulos de proteínas características de doenças neurodegenerativas.

A mitocôndria é um dos principais consumidores de GSH, por conta de seu papel na geração dos radicais livres (Starkov, 2008), alguns trabalhos sobre doença de Huntington mostram declínio dos níveis da GSH antes da disfunção mitocondrial (Liet al., 2010) o que corrobora a hipótese de alteração do tráfego intracelular, associado à proteína Rab11, antes da neurodegeneração.

Sabendo que a rotenona já foi apontada por perturbar os compartimentos de degradação proteica, vale observar que em alguns momentos do trabalho a proteína não se altera ou aumenta em relação ao controle, e o RNA mensageiro diminui, como a Rab 4 e Rab 5 no hipocampo e as Rab 5 e 11 na substância negra. Esses dados sugerem também que possivelmente as vias de degradação podem estar alteradas antes do acúmulo de proteínas insolúveis. 
Nesse estudo nós observamos aumento da expressão gênica da Rab3 na região da substância negra, sabendo que um estudo já demonstrou que no camundongo nocauteado para $\operatorname{Rab} 3$, as vesículas sinápticas estavam distribuídas normalmente, porém o recrutamento dessas vesículas na zona ativa da sinapse diminuiu (Leenders et al., 2001).

Outro estudo também sugere que a Rab3 esteja envolvida no ancoramento de vesículas, pois já foi visto que o ancoramento de vesículas nas células PC 12 foi prejudicada na presença de RNA de interferência e resultou na diminuição da exocitose (Tsuboi e Fukuda, 2006).Em compensação a super expressão da Rab 3A nessas células PC12 aumentou o número de vesículas ancoradas (van Weeringet al., 2007).

Se o aumento do RNA mensageiro refletir nesse caso um aumento de proteína Rab3, talvez na substância negra ocorra um aumento no ancoramento de vesículas sinápticas antes da presença de agregados proteicos.

A Rab 32 teve sua expressão gênica diminuída na região do hipocampo, levando em consideração seu papel no transporte e biogênese mitocondrial, e se a expressão gênica refletir também uma diminuição da expressão da proteína pode-se sugerir que o tráfego mitocondrial possa estar prejudicado antes da formação dos agregados proteicos, mesmo não havendo alteração das proteínas motoras, uma vez que é necessária a interação dos dois tipo de proteínas para que o transporte ocorra.

Na substância negra e no locus coeruleus, a expressão gênica da Rab 32 aumentou, se a expressão proteica acompanhar o aumento de expressão gênica, pode se sugerir que o tráfego esteja alterado nessas regiões, uma vez que a expressão da proteína motora KIF 5 aumentou nas duas regiões também.

As proteínas Rab interagem com diversos componentes dentro da célula, assim como as proteínas motoras (Jordens et al., 2005). Nos neurônios as cinesinas transportam vesículas contendo a proteína precursora amiloide. A Kif $1 \mathrm{~A}$ e a Kif 1B, membros da família da cinesina-3, são responsáveis pelo transporte axonal de vesículas sinápticas (Schimidt e Haucke, 2007). Esses estudos sugerem um papel importante das proteínas GTPases e das proteínas motoras em conjunto, na regulação do tráfego axonal.

A KIF 1B importante também para o correto enovelamento da mielina nos axônios (Lyons et al., 2009), além de ser responsável, em conjunto com outras 
proteínas, pelo transporte anterógrado mitocondrial e de vesículas sinápticas ao longo do axônio(Chung et al., 2009), outros estudos já mostraram que mudanças nos microtúbulos causam inibição no transporte de mitocôndria dependente de cinesina (Ebnethet al., 1998; Bendiskeet al., 2002),

Neste estudo foi observado que os níveis de expressão da KIF 1B na substância negra encontram-se diminuídos com o tratamento de 0,3nM de rotenona em cultura por 24 horas, demonstrando que mecanismos relacionados ao tráfego anterógrado estão acontecendo anteriormente à neurodegeneração.

A diminuição da expressão da KIF 1 leva ao acúmulo da proteína tau em sua forma hiperfosforilada em camundongos, e conduz a axonopathias com ligação anormal do citoesqueleto e proteína precursora amiloide, quadro encontrado em doenças como Alzheimer e Parkinson (Falzone et al., 2009).

Nos casos de doença de Alzheimer já se observou prejuízo no transporte de neurotransmissores essenciais para viabilidade neuronal no hipocampo e em outras regiões. Experimentos realizados em camundongos modelos para doença de Alzheimer mostraram que anormalidades no citoesqueleto precederam a deposição amiloidogênica, sugerindo que defeitos no transporte axonal acontecem nos primeiros estágios da doença (Stokin et al., 2005). Anomalias no citoesqueleto e deposição amiloides com associação a vesículas já foram observados como consequência da dimunição da KIF 1 (Gunawardena e Goldstein, 2001), bem como o tráfego mediado pelas cinesinas encontra-se perturbado na presença de formas patogênicas da proteína tau (Kanaan et al., 2011).

Nesse trabalho foi observado um aumento de expressão da KIF 1 em células de cultura da substância negra depois da exposição a $0,5 \mathrm{nM}$ de rotenona por $48 \mathrm{~h}$, e nossos estudos prévios demonstraram que nesta concentração proteínas características de doenças neurodegenerativas começam a se acumular.

Já foi observado que em casos de doença de Parkinson observa-se agregação da alfa-sinucleína e consequente neurodegeneração na substância negra e outras regiões. Contudo foi observado também que mudanças no transporte anterógrado ocorreram antes da perda neuronal, e a expressão da KIF 1 na substância negra encontra-se aumentada na presença de maiores níveis de alfa-sinucleína (Chunget al., 2009). 
A KIF 5a e KIF 5c são específicas de neurônios (Hirokawa e Takemura, 2005). Essas cinesinas também se movem em direção à região sináptica ao longo dos microtúbulos e são responsáveis pelo transporte da proteína precursora amiloide (Kamal et al., 2000), bem como pela performance do transporte anterógrado mitocondrial (Tanaka et al., 1998).

Nos experimentos realizados nesse trabalho pode-se constatar uma diminuição da expressão da KIF 5 em células de cultura da substância negra depois do tratamento com $0,1 \mathrm{nM}$ por 48 horas, assim como com o tratamento a $0,3 \mathrm{nM}$ por 24 horas em relação ao controle, mas essa última mudança foi revertida após 48 horas de tratamento com $0,3 \mathrm{nM}$ de rotenona, e a expressão da proteína aumentou depois do tratamento com $0,5 \mathrm{nM}$ por $48 \mathrm{~h}$ em relação ao tratamento com $0,1 \mathrm{nM}$ por 48 horas. Esses dados demonstram que a concentração de rotenona e o tempo que as células ficam expostas a rotenona são fatores determinantes que afetam a expressão de proteínas motoras. Em concentrações muito baixas as proteínas motoras apresentam-se com expressão diminuída, mas em concentrações mais altas ou duração maior do tratamento as proteínas motoras retornam ao nível de expressão basal.

Já no locus coeruleus a expressão da KIF 5 aumentou após $0,1 \mathrm{nM}$ de rotenona, tendo diminuído com a concentração de $0,5 \mathrm{nM}$.

O dado acima chamou nossa atenção uma vez que a exposição com apenas $0,1 \mathrm{nM}$ de rotenona por 48 horas já provocou aumento de expressão da KIF 5, enquanto em outras regiões apenas um tratamento com maior concentração de rotenona promoveu aumento de expressão das proteínas motoras. Porém um antigo estudo revelou que os neurônios do locus coeruleus são mais sensíveis, e em casos de doenças neurodegenerativas esta pode ser uma das primeiras regiões afetadas (Arendt, 1995). 
6.Conclusão 
No hipocampo a exposição dos animais a rotenona sugere que o tráfego entre retículo endoplasmático e o Golgi possa estar deficitário uma vez que os níveis protéticos de Rab1 estão diminuídos. Além disso, a via endocítica encontra-se estimulada, pois os níveis proteicos de Rab 4 e Rab 5 encontram-se aumentados, podendo favorecer uma possível captura de proteínas mal formadas como beta-amilóide na presença dos agregados proteicos. Os níveis proteicos da Rab 6 aumentaram também, o que pode ser uma resposta a toxicidade que a célula está exposta neste momento, demonstrando portanto que os níveis de Rab 6 se elevam não só na presença das inclusões proteicas, mas antes da formação das mesmas.

$\mathrm{Na}$ região da substância negra os resultados in vivo sugerem que antes da formação dos agregados proteicos característicos das doenças neurodegenerativas, o tráfego entre o retículo endoplasmático e o Golgi está estimulado e a célula parece estar protegida de possíveis efeitos tóxicos causados por agregados proteicos, uma vez que houve aumento dos níveis de expressão proteica da Rab 1, porém os níveis proteicos de Rab 6 diminuíram, 0 que talvez seja uma resposta protetora, uma vez que a formação de agregados está associada a níveis de Rab 6 aumentados.

Os resultados in vitro revelam que antes da agregação proteica o tráfego de mitocôndrias já pode estar alterado, o que pode conduzir a um quadro de estresse oxidativo na célula, pois as KIF 1B e 5 encontram-se com seus níveis de expressão diminuídos, após o tratamento com $0,1 \mathrm{nM}$ de rotenona por 48 horas, ou 0,3nM por 48 horas. Mas durante a formação dos agregados o tráfego mitocondrial parece ser estimulado, já que os níveis de expressão das KIF 1 e 5 aumentam com o tratamento de $0,5 \mathrm{nM}$ de rotenona por 48 horas.

No locuscoeruleus os resultados in vivo revelam que talvez a célula esteja mais vulnerável aos possíveis fatores que conduzem a neurodegeneração, pois a expressão proteica da Rab 1 encontra-se diminuída e as expressões proteicas da Rab 6 aumentadas, porém os níveis proteicos de Rab 5 e Rab 11 encontramse diminuídos, o que pode conferir proteção à célula, já que altos níveis das proteínas Rabs 5 e 11 acompanham a formação dos agregados, e podem contribuir para aumentar a toxicidade dos mesmos. Já o tráfego mitocondrial 
pode estar alterado, pois a KIF 5 encontra-se com maiores níveis de expressão com o tratamento de $0,1 \mathrm{nM}$ de rotenona por 48 horas, podendo estimular o transporte da organela, entretanto após a exposição com $0,5 \mathrm{nM}$ de rotenona por 48 horas, esse quadro pode ser revertido, uma vez que os níveis de expressão proteicos encontram-se diminuídos.

Contudo, ainda são questões a serem investigadas se a alteração da expressão das proteínas Rab e motoras traduzem-se efetivamente em alteração do tráfego intracelular, ou se a alteração da expressão proteica é reflexo da possível disfunção do sistema de degradação intracelular. 
7.Anexo 


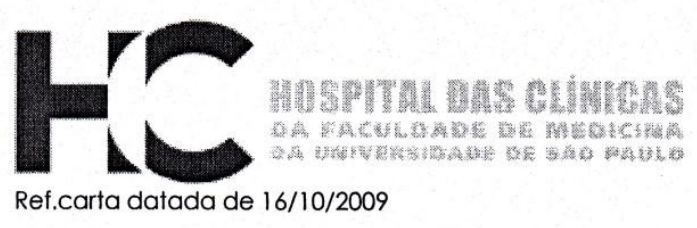

Ao

Departamento de Neurologia

A Comissão de Ética para Análise de Projetos de Pesquisa - CAPPesq da Diretoria Clínica do Hospital das Clínicas e da Faculdade de Medicina da Universidade de São Paulo, em sessão de 04/11//09, tomou conhecimento que o Protocolo de Pesquisa $n^{0}$ 0658/08, intitulado: "ESTUDO DO TRÁFEGO INTRACELULAR ANTES DA FORMAÇÃO DE AGREGADOS PROTÉICOS ENVOLVIDOS NA NEURODEGENERAÇÃO. ÊNFASE NAS PROTEÍNAS RAB", contempla O sub-projeto intitulado "ANÁLISE DA EXPRESSÃO DAS PROTEÍNAS RAB ANTERIOR A AGREGAÇÃO PROTEICA ASSOCIADA A NEURODEGENERAÇÃO", que será Dissertação de Mestrado da IHAIANY QUEVEDO MELO, tendo como orientadora PROFA. DRA. MERARI F. R. FERRARI.

Pesquisador(a) Responsável: PROFA. DRA. MERARI F. R. FERRARI

CAPPesq, 04 de novembro de 2009.

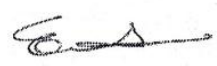

PROF. DR. EDUARDO MASSAD

Presidente da Comissão de Ética para Análise

de Projetos de Pesquisa

\footnotetext{
Comissão de Ética para Análise de Projetos de Pesquisa do HCFMUSP e da FMUSP Diretoria Clínica do Hospital das Clínicas da Faculdade de Medicina da Universidade de São Paulo

Rua Ovídio Pires de Campos. 225, $5^{\circ}$ andar - CEP 05430010 - São Paulo - SP Fone: 011 - $30696442 \mathrm{fax}: 011-30696492$ - e-mail : $\frac{\text { cappesa@ehcnet.usp.br / secretariacappesq2@hcnet.usp.br }}{\mathrm{hF}}$
} 
8.Referências 
Abraham RK, Miller GL (1977) Outpatient argon laser iridectomies for angleclosure glaucoma. A 3 1/2-year study. Adv Ophthalmol 34:186-191.

Almeida CG, Tampellini D, Takahashi RH, Greengard P, Lin MT, Snyder EM, Gouras GK (2005) Beta-amyloid accumulation in APP mutant neurons reduces PSD-95 and GluR1 in synapses. Neurobiol Dis 20:187-198.

Altmam J, Bayers, SA (1995) Atlas of Prenatal Rat Brain Development. Hardcover, CRC.

Alto NM, Soderling J, Scott JD (2002) Rab32 is an A-kinase anchoring protein and participates in mitochondrial dynamics. The Journal of cell biology 158:659-668.

Arendt T, Bruckner MK, Bigl V, Marcova L (1995) Dendritic reorganisation in the basal forebrain under degenerative conditions and its defects in Alzheimer's disease. III. The basal forebrain compared with other subcortical areas. J Comp Neurol 351:223-246.

Auluck PK, Chan HY, Trojanowski JQ, Lee VM, Bonini NM (2002) Chaperone suppression of alpha-synuclein toxicity in a Drosophila model for Parkinson's disease. Science 295:865-868.

Ballatori N, Krance SM, Notenboom S, Shi S, Tieu K, Hammond CL (2009) Glutathione dysregulation and the etiology and progression of human diseases. Biol Chem 390:191-214.

Barbieri MA, Hoffenberg S, Roberts R, Mukhopadhyay A, Pomrehn A, Dickey BF, Stahl PD (1998) Evidence for a symmetrical requirement for Rab5-GTP in in vitro endosome-endosome fusion. J Biol Chem 273:25850-25855.

Bertoni-Freddari C, Fattoretti P, Casoli T, Spagna C, Meier-Ruge W, Ulrich J (1993) Morphological plasticity of synaptic mitochondria during aging. Brain Res 628:193-200.

Bertoni-Freddari C, Fattoretti P, Giorgetti B, Grossi Y, Balietti M, Casoli T, Di Stefano G, Perretta G (2007a) Alterations of synaptic turnover rate in aging may trigger senile plaque formation and neurodegeneration. Ann $\mathrm{N}$ Y Acad Sci 1096:128-137.

Bertoni-Freddari C, Fattoretti P, Giorgetti B, Grossi Y, Balietti M, Casoli T, Di Stefano G, Perretta G (2007b) Preservation of mitochondrial volume homeostasis at the early stages of age-related synaptic deterioration. Ann N Y Acad Sci 1096:138-146.

Bertoni-Freddari C, Fattoretti P, Giorgetti B, Solazzi M, Balietti M, Meier-Ruge W (2004) Role of mitochondrial deterioration in physiological and pathological brain aging. Gerontology 50:187-192.

Billingsley ML, Kincaid RL (1997) Regulated phosphorylation and dephosphorylation of tau protein: effects on microtubule interaction, intracellular trafficking and neurodegeneration. Biochem J 323 ( Pt 3):577591.

Boldogh IR, Pon LA (2007) Mitochondria on the move. Trends in cell biology 17:502-510.

Bonanomi D, Benfenati F, Valtorta F (2006) Protein sorting in the synaptic vesicle life cycle. Prog Neurobiol 80:177-217.

Braak H, Braak E (1991) Neuropathological stageing of Alzheimer-related changes. Acta Neuropathol 82:239-259. 
Bradford MM (1976) A rapid and sensitive method for the quantitation of microgram quantities of protein utilizing the principle of protein-dye binding. Anal Biochem 72:248-254.

Bronfman FC, Escudero CA, Weis J, Kruttgen A (2007) Endosomal transport of neurotrophins: roles in signaling and neurodegenerative diseases. Dev Neurobiol 67:1183-1203.

Brown HM, Van Epps HA, Goncharov A, Grant BD, Jin Y (2009) The JIP3 scaffold protein UNC-16 regulates RAB-5 dependent membrane trafficking at C. elegans synapses. Dev Neurobiol 69:174-190.

Butler D, Brown QB, Chin DJ, Batey L, Karim S, Mutneja MS, Karanian DA, Bahr BA (2005) Cellular responses to protein accumulation involve autophagy and lysosomal enzyme activation. Rejuvenation Res 8:227-237.

Cabin DE, Shimazu K, Murphy D, Cole NB, Gottschalk W, Mcllwain KL, Orrison B, Chen A, Ellis CE, Paylor R, Lu B, Nussbaum RL (2002) Synaptic vesicle depletion correlates with attenuated synaptic responses to prolonged repetitive stimulation in mice lacking alpha-synuclein. $J$ Neurosci 22:8797-8807.

Cai Q, Gerwin C, Sheng ZH (2005) Syntabulin-mediated anterograde transport of mitochondria along neuronal processes. J Cell Biol 170:959-969.

Cataldo AM, Peterhoff CM, Troncoso JC, Gomez-Isla T, Hyman BT, Nixon RA (2000) Endocytic pathway abnormalities precede amyloid beta deposition in sporadic Alzheimer's disease and Down syndrome: differential effects of APOE genotype and presenilin mutations. Am J Pathol 157:277-286.

Cavalli V, Kujala P, Klumperman J, Goldstein LS (2005) Sunday Driver links axonal transport to damage signaling. J Cell Biol 168:775-787.

Chandra S, Gallardo G, Fernandez-Chacon R, Schluter OM, Sudhof TC (2005) Alpha-synuclein cooperates with CSPalpha in preventing neurodegeneration. Cell 123:383-396.

Chaves RS, Melo TQ, Martins SA, Ferrari MF (2010) Protein aggregation containing beta-amyloid, alpha-synuclein and hyperphosphorylated tau in cultured cells of hippocampus, substantia nigra and locus coeruleus after rotenone exposure. BMC Neurosci 11:144.

Chaves S, Mendonca AC, Marques SM, Prata MI, Santos AC, Martins AF, Geraldes CF, Santos MA (2011) A gallium complex with a new tripodal tris-hydroxypyridinone for potential nuclear diagnostic imaging: solution and in vivo studies of 67Ga-labeled species. J Inorg Biochem 105:31-38.

Chuang DM, Hough C, Senatorov VV (2005) Glyceraldehyde-3-phosphate dehydrogenase, apoptosis, and neurodegenerative diseases. Annu Rev Pharmacol Toxicol 45:269-290.

Chung CY, Koprich JB, Siddiqi H, Isacson O (2009) Dynamic changes in presynaptic and axonal transport proteins combined with striatal neuroinflammation precede dopaminergic neuronal loss in a rat model of AAV alpha-synucleinopathy. J Neurosci 29:3365-3373.

Clayton DF, George JM (1999) Synucleins in synaptic plasticity and neurodegenerative disorders. J Neurosci Res 58:120-129.

Cooper AA, Gitler AD, Cashikar A, Haynes CM, Hill KJ, Bhullar B, Liu K, Xu K, Strathearn KE, Liu F, Cao S, Caldwell KA, Caldwell GA, Marsischky G, Kolodner RD, Labaer J, Rochet JC, Bonini NM, Lindquist S (2006) Alphasynuclein blocks ER-Golgi traffic and Rab1 rescues neuron loss in Parkinson's models. Science 313:324-328. 
De Strooper B (2000) Alzheimer's disease. Closing in on gamma-secretase. Nature 405:627, 629.

Delcroix JD, Valletta JS, Wu C, Hunt SJ, Kowal AS, Mobley WC (2003) NGF signaling in sensory neurons: evidence that early endosomes carry NGF retrograde signals. Neuron 39:69-84.

den HJW, Bethlem J (1960) The distribution of Lewy bodies in the central and autonomic nervous systems in idiopathic paralysis agitans. J Neurol Neurosurg Psychiatry 23:283-290.

DerMardirossian C, Bokoch GM (2005) GDIs: central regulatory molecules in Rho GTPase activation. Trends Cell Biol 15:356-363.

Dhani SU, Kim Chiaw P, Huan LJ, Bear CE (2008) ATP depletion inhibits the endocytosis of CIC-2. J Cell Physiol 214:273-280.

Diaz-Corrales FJ, Asanuma M, Miyazaki I, Miyoshi K, Ogawa N (2005) Rotenone induces aggregation of gamma-tubulin protein and subsequent disorganization of the centrosome: relevance to formation of inclusion bodies and neurodegeneration. Neuroscience 133:117-135.

Dringen R (2000) Metabolism and functions of glutathione in brain. Prog Neurobiol 62:649-671.

Ebneth A, Godemann R, Stamer K, Illenberger S, Trinczek B, Mandelkow E (1998) Overexpression of tau protein inhibits kinesin-dependent trafficking of vesicles, mitochondria, and endoplasmic reticulum: implications for Alzheimer's disease. J Cell Biol 143:777-794.

Esiri MM (2007) Ageing and the brain. J Pathol 211:181-187.

Falzone TL, Stokin GB, Lillo C, Rodrigues EM, Westerman EL, Williams DS, Goldstein LS (2009) Axonal stress kinase activation and tau misbehavior induced by kinesin-1 transport defects. J Neurosci 29:5758-5767.

Ferrante RJ, Schulz JB, Kowall NW, Beal MF (1997) Systemic administration of rotenone produces selective damage in the striatum and globus pallidus, but not in the substantia nigra. Brain Res 753:157-162.

Fischer von Mollard G, Stahl B, Walch-Solimena C, Takei K, Daniels L, Khoklatchev A, De Camilli P, Sudhof TC, Jahn R (1994) Localization of Rab5 to synaptic vesicles identifies endosomal intermediate in synaptic vesicle recycling pathway. Eur J Cell Biol 65:319-326.

Fleming J, Outeiro TF, Slack M, Lindquist SL, Bulawa CE (2008) Detection of compounds that rescue Rab1-synuclein toxicity. Methods in enzymology 439:339-351.

Forloni G, Bertani I, Calella AM, Thaler F, Invernizzi R (2000) Alpha-synuclein and Parkinson's disease: selective neurodegenerative effect of alphasynuclein fragment on dopaminergic neurons in vitro and in vivo. Ann Neurol 47:632-640.

Fortin DL, Troyer MD, Nakamura K, Kubo S, Anthony MD, Edwards RH (2004) Lipid rafts mediate the synaptic localization of alpha-synuclein. J Neurosci 24:6715-6723.

Fountaine TM, Wade-Martins R (2007) RNA interference-mediated knockdown of alpha-synuclein protects human dopaminergic neuroblastoma cells from $\mathrm{MPP}(+)$ toxicity and reduces dopamine transport. J Neurosci Res 85:351363.

Furman CA, Lo CB, Stokes S, Esteban JA, Gnegy ME (2009) Rab 11 regulates constitutive dopamine transporter trafficking and function in N2A neuroblastoma cells. Neuroscience letters 463:78-81. 
Ganzer S, Arlt S, Schoder V, Buhmann C, Mandelkow EM, Finckh U, Beisiegel U, Naber D, Muller-Thomsen T (2003) CSF-tau, CSF-Abeta1-42, ApoEgenotype and clinical parameters in the diagnosis of Alzheimer's disease: combination of CSF-tau and MMSE yields highest sensitivity and specificity. J Neural Transm 110:1149-1160.

Gentile A, Amadoro G, Corsetti V, Ciotti MT, Serafino A, Calissano P (2008) Spontaneous aggregation and altered intracellular distribution of endogenous alpha-synuclein during neuronal apoptosis. J Alzheimers Dis 13:151-160.

Geppert M, Goda Y, Stevens CF, Sudhof TC (1997) The small GTP-binding protein $\mathrm{Rab} 3 \mathrm{~A}$ regulates a late step in synaptic vesicle fusion. Nature 387, 810-814.

Gitler AD, Bevis BJ, Shorter J, Strathearn KE, Hamamichi S, Su LJ, Caldwell KA, Caldwell GA, Rochet JC, McCaffery JM, Barlowe C, Lindquist S (2008) The Parkinson's disease protein alpha-synuclein disrupts cellular Rab homeostasis. Proc Natl Acad Sci U S A 105:145-150.

Gonatas NK, Stieber A, Gonatas JO (2006) Fragmentation of the Golgi apparatus in neurodegenerative diseases and cell death. J Neurol Sci 246:21-30.

Gouras GK, Almeida CG, Takahashi RH (2005) Intraneuronal Abeta accumulation and origin of plaques in Alzheimer's disease. Neurobiol Aging 26:1235-1244.

Guidetti C, Paracchini S, Lucchini S, Cambieri M, Marzatico F (2001) Prevention of neuronal cell damage induced by oxidative stress in-vitro: effect of different Ginkgo biloba extracts. J Pharm Pharmacol 53:387-392.

Gunawardena S, Goldstein LS (2001) Disruption of axonal transport and neuronal viability by amyloid precursor protein mutations in Drosophila. Neuron 32:389-401.

Haass C (2004) Take five--BACE and the gamma-secretase quartet conduct Alzheimer's amyloid beta-peptide generation. EMBO J 23:483-488.

Haass C, Koo EH, Mellon A, Hung AY, Selkoe DJ (1992) Targeting of cellsurface beta-amyloid precursor protein to lysosomes: alternative processing into amyloid-bearing fragments. Nature 357:500-503.

Haass C, Selkoe DJ (2007) Soluble protein oligomers in neurodegeneration: lessons from the Alzheimer's amyloid beta-peptide. Nat Rev Mol Cell Biol 8:101-112.

Hammer JA, 3rd, Wu XS (2002) Rabs grab motors: defining the connections between Rab GTPases and motor proteins. Curr Opin Cell Biol 14:69-75.

Harrison RS, Sharpe PC, Singh Y, Fairlie DP (2007) Amyloid peptides and proteins in review. Rev Physiol Biochem Pharmacol 159:1-77.

Heikkila RE, Nicklas WJ, Vyas I, Duvoisin RC (1985) Dopaminergic toxicity of rotenone and the 1-methyl-4-phenylpyridinium ion after their stereotaxic administration to rats: implication for the mechanism of 1-methyl-4-phenyl1,2,3,6-tetrahydropyridine toxicity. Neurosci Lett 62:389-394.

Herrera E, Caramelli P, Nitrini R (1998) Estudo epidemiológico populacional de demência na cidade de Catanduva, Estado de São Paulo, Brasil. Rev Psiquiatr Clin 25:70-73.

Hirokawa N, Noda Y, Tanaka Y, Niwa S (2009) Kinesin superfamily motor proteins and intracellular transport. Nat Rev Mol Cell Biol 10:682-696.

Hollenbeck PJ, Saxton WM (2005) The axonal transport of mitochondria. J Cell Sci 118:5411-5419. 
Honson NS, Kuret $J$ (2008) Tau aggregation and toxicity in tauopathic neurodegenerative diseases. J Alzheimers Dis 14:417-422.

Horgan CP, McCaffrey MW (2011) Rab GTPases and microtubule motors. Biochem Soc Trans 39:1202-1206.

Hoshino T, Namba T, Takehara M, Nakaya T, Sugimoto Y, Araki W, Narumiya S, Suzuki T, Mizushima T (2009) Prostaglandin E2 stimulates the production of amyloid-beta peptides through internalization of the EP4 receptor. J Biol Chem 284:18493-18502.

Huang J, Xiong N, Chen C, Xiong J, Jia M, Zhang Z, Cao X, Liang Z, Sun S, Lin Z, Wang T (2011) Glyceraldehyde-3-phosphate dehydrogenase: activity inhibition and protein overexpression in rotenone models for Parkinson's disease. Neuroscience 192:598-608.

Ishitani R, Chuang DM (1996) Glyceraldehyde-3-phosphate dehydrogenase antisense oligodeoxynucleotides protect against cytosine arabinonucleoside-induced apoptosis in cultured cerebellar neurons. Proc Natl Acad Sci U S A 93:9937-9941.

Jeannotte AM, Sidhu A (2007) Regulation of the norepinephrine transporter by alpha-synuclein-mediated interactions with microtubules. Eur J Neurosci 26:1509-1520.

Jordens I, Marsman M, Kuijl C, Neefjes J (2005) Rab proteins, connecting transport and vesicle fusion. Traffic 6:1070-1077.

Kaasinen SK, Harvey L, Reynolds AJ, Hendry IA (2008) Autophagy generates retrogradely transported organelles: a hypothesis. Int $\mathrm{J}$ Dev Neurosci 26:625-634.

Kakita A, Takahashi H, Homma Y, Ikuta F (1994) Lewy bodies in the cerebellar dentate nucleus of a patient with Parkinson's disease. Pathol Int 44:878880.

Kamal A, Stokin GB, Yang Z, Xia CH, Goldstein LS (2000) Axonal transport of amyloid precursor protein is mediated by direct binding to the kinesin light chain subunit of kinesin-I. Neuron 28:449-459.

Kanaan NM, Morfini GA, LaPointe NE, Pigino GF, Patterson KR, Song Y, Andreadis A, Fu Y, Brady ST, Binder LI (2011) Pathogenic forms of tau inhibit kinesin-dependent axonal transport through a mechanism involving activation of axonal phosphotransferases. J Neurosci 31:9858-9868.

Kivell BM, McDonald FJ, Miller JH (2001) Method for serum-free culture of late fetal and early postnatal rat brainstem neurons. Brain Res Brain Res Protoc 6:91-99.

Klegeris A, Pelech S, Giasson BI, Maguire J, Zhang H, McGeer EG, McGeer PL (2008) Alpha-synuclein activates stress signaling protein kinases in THP-1 cells and microglia. Neurobiol Aging 29:739-752.

Kordower JH, Chu Y, Hauser RA, Freeman TB, Olanow CW (2008) Lewy bodylike pathology in long-term embryonic nigral transplants in Parkinson's disease. Nat Med 14:504-506.

Kornmann B, Currie E, Collins SR, Schuldiner M, Nunnari J, Weissman JS, Walter $P$ (2009) An ER-mitochondria tethering complex revealed by a synthetic biology screen. Science 325:477-481.

Kubo S, Nemani VM, Chalkley RJ, Anthony MD, Hattori N, Mizuno Y, Edwards $\mathrm{RH}$, Fortin DL (2005) A combinatorial code for the interaction of alphasynuclein with membranes. J Biol Chem 280:31664-31672. 
Kuwahara T, Koyama A, Koyama S, Yoshina S, Ren CH, Kato T, Mitani S, Iwatsubo T (2008) A systematic RNAi screen reveals involvement of endocytic pathway in neuronal dysfunction in alpha-synuclein transgenic C. elegans. Hum Mol Genet 17:2997-3009.

Lantos PL, Papp MI (1994) Cellular pathology of multiple system atrophy: a review. J Neurol Neurosurg Psychiatry 57:129-133.

Larsen KE, Schmitz Y, Troyer MD, Mosharov E, Dietrich P, Quazi AZ, Savalle M, Nemani V, Chaudhry FA, Edwards RH, Stefanis L, Sulzer D (2006) Alphasynuclein overexpression in PC12 and chromaffin cells impairs catecholamine release by interfering with a late step in exocytosis. J Neurosci 26:11915-11922.

Lee HJ, Khoshaghideh F, Lee S, Lee SJ (2006) Impairment of microtubuledependent trafficking by overexpression of alpha-synuclein. Eur $\mathrm{J}$ Neurosci 24:3153-3162.

Lee VM, Trojanowski JQ (2006) Mechanisms of Parkinson's disease linked to pathological alpha-synuclein: new targets for drug discovery. Neuron 52:33-38.

Leenders AG, Lopes da Silva, FH, Ghijsen WE, Verhage M. Rab 3a is involved in transport of sinaptic vesicles to the active zone in mouse brain nerve terminals. Mol. Biol. Cell 2001; 12:309 5-3102.

Li X, Valencia A, Sapp E, Masso N, Alexander J, Reeves P, Kegel KB, Aronin N, Difiglia M (2010) Aberrant Rab11-dependent trafficking of the neuronal glutamate transporter EAAC1 causes oxidative stress and cell death in Huntington's disease. J Neurosci 30:4552-4561.

Liu J, Zhang JP, Shi M, Quinn T, Bradner J, Beyer R, Chen S, Zhang J (2009) Rab11a and HSP90 regulate recycling of extracellular alpha-synuclein. J Neurosci 29:1480-1485.

Lu B (2009) Mitochondrial dynamics and neurodegeneration. Curr Neurol Neurosci Rep 9:212-219.

Lyons DA, Naylor SG, Scholze A, Talbot WS (2009) Kif1b is essential for mRNA localization in oligodendrocytes and development of myelinated axons. Nat Genet 41:854-858.

Mandelkow EM, Stamer K, Vogel R, Thies E, Mandelkow E (2003) Clogging of axons by tau, inhibition of axonal traffic and starvation of synapses. Neurobiol Aging 24:1079-1085.

Marques SC, Oliveira CR, Pereira CM, Outeiro TF (2011) Epigenetics in neurodegeneration: a new layer of complexity. Prog Neuropsychopharmacol Biol Psychiatry 35:348-355.

Martin LJ (2007) Transgenic mice with human mutant genes causing Parkinson's disease and amyotrophic lateral sclerosis provide common insight into mechanisms of motor neuron selective vulnerability to degeneration. Rev Neurosci 18:115-136.

Mayeux R (2003) Epidemiology of neurodegeneration. Annu Rev Neurosci 26:81104.

McConlogue L, Castellano F, deWit C, Schenk D, Maltese WA (1996) Differential effects of a Rab6 mutant on secretory versus amyloidogenic processing of Alzheimer's beta-amyloid precursor protein. J Biol Chem 271:1343-1348.

Mercer TR, Dinger ME, Sunkin SM, Mehler MF, Mattick JS (2008) Specific expression of long noncoding RNAs in the mouse brain. Proc Natl Acad Sci U S A 105:716-721. 
Mezey E, Dehejia A, Harta G, Papp MI, Polymeropoulos MH, Brownstein MJ (1998) Alpha synuclein in neurodegenerative disorders: murderer or accomplice? Nat Med 4:755-757.

Muller WE, Eckert A, Kurz C, Eckert GP, Leuner K (2010) Mitochondrial dysfunction: common final pathway in brain aging and Alzheimer's disease--therapeutic aspects. Mol Neurobiol 41:159-171.

Nagele RG, D'Andrea MR, Anderson WJ, Wang HY (2002) Intracellular accumulation of beta-amyloid(1-42) in neurons is facilitated by the alpha 7 nicotinic acetylcholine receptor in Alzheimer's disease. Neuroscience 110:199-211.

Nangaku M, Sato-Yoshitake R, Okada Y, Noda Y, Takemura R, Yamazaki H, Hirokawa N (1994) KIF1B, a novel microtubule plus end-directed monomeric motor protein for transport of mitochondria. Cell 79:1209-1220.

Nemani VM, Lu W, Berge V, Nakamura K, Onoa B, Lee MK, Chaudhry FA, Nicoll RA, Edwards RH (2010) Increased expression of alpha-synuclein reduces neurotransmitter release by inhibiting synaptic vesicle reclustering after endocytosis. Neuron 65:66-79.

Nixon RA (2005) Endosome function and dysfunction in Alzheimer's disease and other neurodegenerative diseases. Neurobiol Aging 26:373-382.

Nonet ML, Staunton JE, Kilgard MP, Fergestad T, Hartwieg E, Horvitz HR, Jorgen sen EM, Meyer BJ. Caenorhabditis elegans rab-3 mutant synapses exhibit impaired function and are partially depleted of vesicles. J. Neurosci 1997; 17: 8061-8073.

Novick P, Brennwald P (1993) Friends and family: the role of the Rab GTPases in vesicular traffic. Cell 75:597-601.

Oddo S, Caccamo A, Smith IF, Green KN, LaFerla FM (2006) A dynamic relationship between intracellular and extracellular pools of Abeta. Am J Pathol 168:184-194.

Ohama E, Ikuta F (1976) Parkinson's disease: distribution of Lewy bodies and monoamine neuron system. Acta Neuropathol 34:311-319.

Olchowik M, Miaczynska M (2009) [Effectors of GTPase Rab5 in endocytosis and signal transduction]. Postepy Biochem 55:171-180.

Orr AL, Li S, Wang CE, Li H, Wang J, Rong J, Xu X, Mastroberardino PG, Greenamyre JT, Li XJ (2008) N-terminal mutant huntingtin associates with mitochondria and impairs mitochondrial trafficking. J Neurosci 28:27832792.

Outeiro TF, Lindquist S (2003) Yeast cells provide insight into alpha-synuclein biology and pathobiology. Science 302:1772-1775.

Pan X, Eathiraj S, Munson M, Lambright DG (2006) TBC-domain GAPs for Rab GTPases accelerate GTP hydrolysis by a dual-finger mechanism. Nature 442:303-306.

Pereira-Leal JB, Seabra MC (2001) Evolution of the Rab family of small GTPbinding proteins. J Mol Biol 313:889-901.

Pierce JP, Mayer T, McCarthy JB (2001) Evidence for a satellite secretory pathway in neuronal dendritic spines. Curr Biol 11:351-355.

Querfurth HW, LaFerla FM (2010) Alzheimer's disease. N Engl J Med 362:329344.

Reddy PH (2009) Amyloid beta, mitochondrial structural and functional dynamics in Alzheimer's disease. Exp Neurol 218:286-292. 
Rizzoli SO, Bethani I, Zwilling D, Wenzel D, Siddiqui TJ, Brandhorst D, Jahn R (2006) Evidence for early endosome-like fusion of recently endocytosed synaptic vesicles. Traffic 7:1163-1176.

Ryu EJ, Harding HP, Angelastro JM, Vitolo OV, Ron D, Greene LA (2002) Endoplasmic reticulum stress and the unfolded protein response in cellular models of Parkinson's disease. J Neurosci 22:10690-10698.

Scazufca $M$, Cerqueira A, Menezes $P$, Prince $M$, Vallada $H$, Miyazaki $M$, Domingos N, Antunes E, Macedo G, Almeida S, Matsuda C (2002) Investigações epidemiológicas sobre demência nos países em desenvolvimento. Rev Saúde Pública 36:773-778.

Scheper W, Hoozemans JJ, Hoogenraad CC, Rozemuller AJ, Eikelenboom P, Baas F (2007) Rab6 is increased in Alzheimer's disease brain and correlates with endoplasmic reticulum stress. Neuropathol Appl Neurobiol 33:523-532.

Schmidt MR, Haucke V (2007) Recycling endosomes in neuronal membrane traffic. Biol Cell 99:333-342.

Scott DA, Tabarean I, Tang Y, Cartier A, Masliah E, Roy S (2010) A pathologic cascade leading to synaptic dysfunction in alpha-synuclein-induced neurodegeneration. J Neurosci 30:8083-8095.

Shalova IN, Cechalova K, Rehakova Z, Dimitrova P, Ognibene E, Caprioli A, Schmalhausen EV, Muronetz VI, Saso L (2007) Decrease of dehydrogenase activity of cerebral glyceraldehyde-3-phosphate dehydrogenase in different animal models of Alzheimer's disease. Biochim Biophys Acta 1770:826-832.

Shinohara M, Sato N, Kurinami $H$, Takeuchi D, Takeda S, Shimamura M, Yamashita T, Uchiyama Y, Rakugi H, Morishita R (2010) Reduction of brain beta-amyloid (Abeta) by fluvastatin, a hydroxymethylglutaryl-CoA reductase inhibitor, through increase in degradation of amyloid precursor protein C-terminal fragments (APP-CTFs) and Abeta clearance. J Biol Chem 285:22091-22102.

Sisodia SS, St George-Hyslop PH (2002) gamma-Secretase, Notch, Abeta and Alzheimer's disease: where do the presenilins fit in? Nat Rev Neurosci 3:281-290.

Soane L, Kahraman S, Kristian T, Fiskum G (2007) Mechanisms of impaired mitochondrial energy metabolism in acute and chronic neurodegenerative disorders. J Neurosci Res 85:3407-3415.

Song MS, Baker GB, Todd KG, Kar S (2011) Inhibition of beta-amyloid1-42 internalization attenuates neuronal death by stabilizing the endosomallysosomal system in rat cortical cultured neurons. Neuroscience 178:181188.

Soper JH, Kehm V, Burd CG, Bankaitis VA, Lee VM (2011) Aggregation of alphasynuclein in $\mathrm{S}$. cerevisiae is associated with defects in endosomal trafficking and phospholipid biosynthesis. J Mol Neurosci 43:391-405.

Starkov AA (2008) The role of mitochondria in reactive oxygen species metabolism and signaling. Ann N Y Acad Sci 1147:37-52.

Stenmark H (2009) Rab GTPases as coordinators of vesicle traffic. Nature reviews 10:513-525.

Stenmark H, Olkkonen VM (2001) The Rab GTPase family. Genome Biol 2:REVIEWS3007. 
Stokin GB, Lillo C, Falzone TL, Brusch RG, Rockenstein E, Mount SL, Raman R, Davies P, Masliah E, Williams DS, Goldstein LS (2005) Axonopathy and transport deficits early in the pathogenesis of Alzheimer's disease. Science 307:1282-1288.

Stowers RS, Megeath LJ, Gorska-Andrzejak J, Meinertzhagen IA, Schwarz TL (2002) Axonal transport of mitochondria to synapses depends on milton, a novel Drosophila protein. Neuron 36:1063-1077.

Sung JY, Kim J, Paik SR, Park JH, Ahn YS, Chung KC (2001) Induction of neuronal cell death by Rab5A-dependent endocytosis of alpha-synuclein. J Biol Chem 276:27441-27448.

Tanaka Y, Kanai Y, Okada Y, Nonaka S, Takeda S, Harada A, Hirokawa N (1998) Targeted disruption of mouse conventional kinesin heavy chain, kif5B, results in abnormal perinuclear clustering of mitochondria. Cell 93:1147-1158.

Trzesniewska K, Brzyska M, Elbaum D (2004) Neurodegenerative aspects of protein aggregation. Acta Neurobiol Exp (Wars) 64:41-52.

Tsuboi T, Fukuda M. Rab 3A e Rab 27A cooperatively regulate the docking step of dense-core vesicle exocitosis in PC12 cells. J Cell Sci 2006; 119: 21962203.

Ullrich C, Humpel C (2009) Rotenone induces cell death of cholinergic neurons in an organotypic co-culture brain slice model. Neurochem Res 34:21472153.

Van Laar VS, Berman SB (2009) Mitochondrial dynamics in Parkinson's disease. Exp Neurol 218:247-256.

van Weering JR, Toonen RF, Verhage M. The role of Rab 3a in secretory vesicle docking requeires association/ dissociation of guanidine phosphates and Muncl 8-1. PLoS One 2007; 2 e 616.

Wakabayashi K, Takahashi H (1997) Neuropathology of autonomic nervous system in Parkinson's disease. Eur Neurol 38 Suppl 2:2-7.

Wakabayashi K, Tanji K, Mori F, Takahashi H (2007) The Lewy body in Parkinson's disease: molecules implicated in the formation and degradation of alpha-synuclein aggregates. Neuropathology 27:494-506.

Wallace DC (2005) A mitochondrial paradigm of metabolic and degenerative diseases, aging, and cancer: a dawn for evolutionary medicine. Annu Rev Genet 39:359-407.

Wang Y, Tang BL (2006) SNAREs in neurons--beyond synaptic vesicle exocytosis (Review). Mol Membr Biol 23:377-384.

Weintraub D, Comella CL, Horn S (2008) Parkinson's disease--Part 1: Pathophysiology, symptoms, burden, diagnosis, and assessment. Am J Manag Care 14:S40-48.

Woltjer RL, Sonnen JA, Sokal I, Rung LG, Yang W, Kjerulf JD, Klingert D, Johnson C, Rhew I, Tsuang D, Crane PK, Larson EB, Montine TJ (2009) Quantitation and mapping of cerebral detergent-insoluble proteins in the elderly. Brain Pathol 19:365-374.

Xu J, Kao SY, Lee FJ, Song W, Jin LW, Yankner BA (2002) Dopaminedependent neurotoxicity of alpha-synuclein: a mechanism for selective neurodegeneration in Parkinson disease. Nat Med 8:600-606.

Ye H, Kuruvilla R, Zweifel LS, Ginty DD (2003) Evidence in support of signaling endosome-based retrograde survival of sympathetic neurons. Neuron 39:57-68. 
Yoshida M (2007) Multiple system atrophy: alpha-synuclein and neuronal degeneration. Neuropathology 27:484-493.

Yu S, Li X, Liu G, Han J, Zhang C, Li Y, Xu S, Liu C, Gao Y, Yang H, Ueda K, Chan $P$ (2007) Extensive nuclear localization of alpha-synuclein in normal rat brain neurons revealed by a novel monoclonal antibody. Neuroscience 145:539-555.

Zerial M, McBride H (2001) Rab proteins as membrane organizers. Nat Rev Mol Cell Biol 2:107-117.

Zhang W, Wang T, Pei Z, Miller DS, Wu X, Block ML, Wilson B, Zhou Y, Hong JS, Zhang J (2005) Aggregated alpha-synuclein activates microglia: a process leading to disease progression in Parkinson's disease. FASEB $\mathrm{J}$ 19:533-542.

Zhao C, Slevin JT, Whiteheart SW (2007) Cellular functions of NSF: not just SNAPs and SNAREs. FEBS Lett 581:2140-2149. 